\title{
Metastable Metal Hydrides for Hydrogen Storage
}

\author{
Jason Graetz \\ Department of Sustainable Energy Technologies, Brookhaven National Laboratory, Upton, NY 11973, USA \\ Correspondence should be addressed to Jason Graetz, graetz@bnl.gov
}

Received 3 October 2012; Accepted 29 October 2012

Academic Editors: G. C. Mather and A. O. Neto

Copyright ( 2012 Jason Graetz. This is an open access article distributed under the Creative Commons Attribution License, which permits unrestricted use, distribution, and reproduction in any medium, provided the original work is properly cited.

\begin{abstract}
The possibility of using hydrogen as a reliable energy carrier for both stationary and mobile applications has gained renewed interest in recent years due to improvements in high temperature fuel cells and a reduction in hydrogen production costs. However, a number of challenges remain and new media are needed that are capable of safely storing hydrogen with high gravimetric and volumetric densities. Metal hydrides and complex metal hydrides offer some hope of overcoming these challenges; however, many of the high capacity "reversible" hydrides exhibit a large endothermic decomposition enthalpy making it difficult to release the hydrogen at low temperatures. On the other hand, the metastable hydrides are characterized by a low reaction enthalpy and a decomposition reaction that is thermodynamically favorable under ambient conditions. The rapid, low temperature hydrogen evolution rates that can be achieved with these materials offer much promise for mobile PEM fuel cell applications. However, a critical challenge exists to develop new methods to regenerate these hydrides directly from the reactants and hydrogen gas. This spotlight paper presents an overview of some of the metastable metal hydrides for hydrogen storage and a few new approaches being investigated to address the key challenges associated with these materials.
\end{abstract}

\section{Introduction}

The doubling of the world's energy consumption over the next fifty years [1] will require significant changes in the way we produce, distribute, store, and use energy. A crucial step in this process will be reducing our dependence on carbonbased fossil fuels. The rapidly growing global demand for oil will likely outpace production within a few decades (if it has not already). Although petroleum fuels can be produced from coal through a Fischer-Tropsch process, this method is costly and will likely result in greater greenhouse gas (e.g., $\mathrm{CO}_{2}$ ) emissions. Hydrogen is a versatile, clean energy carrier that can be produced from natural gas reforming and a variety of carbon free energy sources such as solar, wind, and nuclear energy through water electrolysis. Hydrogen can easily be converted into mechanical or electrical energy through a combustion reaction or fuel cell, respectively. In both cases the hydrogen reacts with oxygen to produce water and energy $\left(2 \mathrm{H}_{2}^{\mathrm{g}}+\mathrm{O}_{2}^{\mathrm{g}} \rightarrow 2 \mathrm{H}_{2} \mathrm{O}^{\mathrm{g}}\right.$ with a theoretical energy of theoretical energy density of $120 \mathrm{~kJ} / \mathrm{g}$ ).

Hydrogen storage remains one of the more challenging technological barriers to the advancement of hydrogen fuel cell technologies for mobile applications. Since hydrogen is a gas at standard pressure and temperature (SPT), it has a low volumetric density. Although one kilogram of $\mathrm{H}_{2}$ can replace about $3 \mathrm{~kg}$ or one gallon $(3.79 \mathrm{~L})$ of gasoline, on a volumetric scale more than 3500 gallons $\left(1.3 \times 10^{4} \mathrm{~L} \approx\right.$ volume of a midsize car) of $\mathrm{H}_{2}$ gas is necessary to replace just one gallon $(3.79 \mathrm{~L})$ of gasoline at SPT.

There are a variety of ways to store hydrogen (as shown in Figure 1), and the more conventional methods include compressed gas (typically 350 or 700 bar) and liquefaction, where the hydrogen is cooled to below its boiling point $(20 \mathrm{~K})$. However, these options are costly and require extremely high pressures or low temperatures to achieve reasonable hydrogen densities. Solid-state hydrogen storage, where the hydrogen is either attached onto the surface (adsorption) or inserted into a host material, offers improved volumetric energy densities at moderate pressures and temperatures. In fact, many metal hydrides have a hydrogen density greater than that of liquid hydrogen (Figure 1). Most hydrogen storage materials can be divided into two categories, those that bind molecular hydrogen to surfaces via weak dipole (van der Waals) interactions (typically $<10 \mathrm{~kJ} / \mathrm{mol} \mathrm{H}_{2}$ ) [2] 


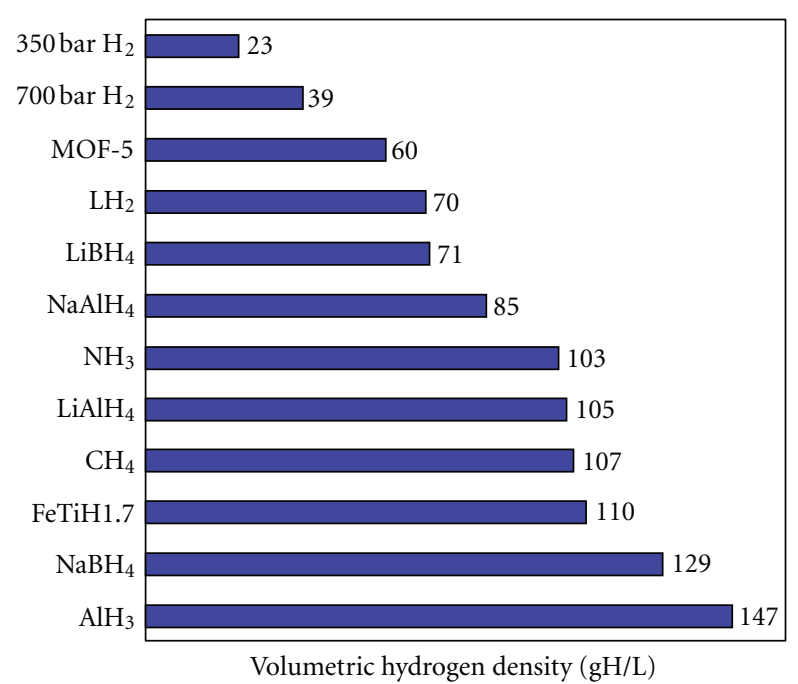

Figure 1: Volumetric hydrogen density ( $\mathrm{gH} / \mathrm{L})$ of a variety of hydrogen storage methods including compressed gas (350 and 700 bar), physisorption in a metal organic framework (MOF), liquid hydrogen $\left(\mathrm{LH}_{2}\right)$, ammonia $\left(\mathrm{NH}_{3}\right)$, methane $\left(\mathrm{CH}_{4}\right)$, and a variety of metal and complex hydrides. The values present in this graph are only for the storage medium and do not take into account the full system volume (e.g., tank and fuel cell).

in a process known as physisorption (e.g., activated carbons and metal organic frameworks (MOFs) and those that trap atomic hydrogen via a strong (typically $>10 \mathrm{~kJ} / \mathrm{mol} \mathrm{H}_{2}$ ) chemical bond (e.g., metal hydrides, complex hydrides and chemical hydrides). There has been tremendous progress in the development of new physisorbents for hydrogen storage in recent years [3-8]; however, these materials typically exhibit appreciable storage capacities (e.g., $>2 \mathrm{wt} . \%$ ) only at low temperature (e.g., $77 \mathrm{~K}$ ).

\section{Metal Hydrides and Complex Hydrides}

Hydrogen storage materials that store atomic hydrogen through a chemical bond are often categorized by their "reversibility", or their ability to be rehydrogenated under moderate temperature and pressure conditions. Recently, much attention has been focused on reversible complex metal hydrides, specifically sodium aluminum hydride $\left(\mathrm{NaAlH}_{4}\right)$. During thermal decomposition of catalyzed $\mathrm{NaAlH}_{4}$ (typically $2-4 \mathrm{~mol} \% \mathrm{Ti}$ ) approximately $4 \mathrm{wt} . \%$ of hydrogen is released at a temperature of around $160^{\circ} \mathrm{C}$. Most importantly, the dehydrogenated material $(\mathrm{NaH}+$ Al) can be rehydrogenated under moderate conditions [9]. The demonstration of reversible hydrogen cycling in the complex metal hydrides was a breakthrough in solid-state hydrogen storage. Catalyzed sodium aluminum hydride is capable of cycling approximately twice the hydrogen (on a weight basis) of any of the conventional metal hydrides (e.g., FeTiHx). Since this discovery, hydrogen reversibility has been demonstrated in other complex hydrides including $\mathrm{Na}_{2} \mathrm{LiAlH}_{6}, \mathrm{KAlH}_{4}, \mathrm{~K}_{3} \mathrm{AlH}_{6}, \mathrm{~K}_{2} \mathrm{LiAlH}_{6}$, and $\mathrm{K}_{2} \mathrm{NaAlH}_{6}$ [9$11]$.
Despite the recent progress in the development of new reversible complex hydrides for hydrogen storage, systems based on these materials have an inherent heat problem, which poses a significant engineering challenge for on-board refueling. This problem is due to the large hydrogenation enthalpy (typically greater than $33 \mathrm{~kJ} / \mathrm{mol} \mathrm{H}_{2}$ ) characteristic of metal hydrides reversible at around $100^{\circ} \mathrm{C}$. The large enthalpy is necessary to offset the large entropy change (110$130 \mathrm{~J} / \mathrm{K} \mathrm{mol} \mathrm{H}_{2}$ ) during hydrogenation and achieve a nearzero free energy change. Based on a generic reversible hydride with a slightly positive free energy (so that $\mathrm{H}_{2}$ is released at pressures above $1 \mathrm{~atm}$ ) and a $5 \mathrm{~kg} \mathrm{H}_{2}$ tank, approximately $83 \mathrm{MJ}$ of heat is released during hydrogenation. Although this is a lot of wasted energy, the real problem arises when we consider the rapid refueling rates necessary to complete the process in approximately 3 minutes $\left(1.67 \mathrm{~kg} \mathrm{H}_{2} / \mathrm{min}\right)$. The $83 \mathrm{MJ}$ of heat generated during refueling will need to be dissipated at a rate of $\sim 0.5 \mathrm{MW}$, which is an extremely challenging engineering problem that is not likely to be solved by moderate improvements in heat exchangers [12]. The large reaction enthalpy also presents a problem for the decomposition reaction since a substantial heat exchange system is required to provide the heat necessary to release the $\mathrm{H}_{2}$ at a rate to satisfy the fuel cell demand.

\section{Chemical Hydrides}

Given the challenges associated with adsorbents (low gravimetric capacity at room temperature) and the reversible hydrides (low gravimetric capacity and large heats of reaction), there has been a growing interest in the chemical hydrides, which offer high capacity and rapid hydrogen rates at low temperature. However, these hydrides are not directly reversible under moderate hydrogenation conditions and typically require "off-board" chemical regeneration. Since the barrier to hydrogenation can be thermodynamic, kinetic, or both, these materials can have a range of decomposition enthalpies from weak (e.g., $\mathrm{AlH}_{3} \Delta H=7 \mathrm{~kJ} / \mathrm{mol} \mathrm{H}_{2}$ ) to strong (e.g., $\mathrm{LiBH}_{4} \Delta H=67 \mathrm{~kJ} / \mathrm{mol} \mathrm{H}_{2}$ for partial decomposition). For the more stable compounds, such as $\mathrm{NaBH}_{4}$, the hydrogen is typically generated through a low temperature hydrolysis reaction:

$$
\mathrm{NaBH}_{4}+2 \mathrm{H}_{2} \mathrm{O} \longrightarrow \mathrm{NaBO}_{2}+4 \mathrm{H}_{2}
$$

In this type of system, a large amount of hydrogen can be generated at rapid rates that easily meet the US Department of Energy's fuel flow rate target $0.02 \mathrm{gs}^{-1} \mathrm{~kW}^{-1}$. These types of reactions are useful for some applications, especially when water is easily accessible (e.g., marine applications), but there are also a number of limitations, namely, regeneration of the spent fuel. After hydrolysis the reactants are left in deep thermodynamic well that makes the regeneration (refueling) process economically and energetically costly.

On the other end of the spectrum, there is a class of weakly bound chemical hydrides that can release hydrogen at rapid rates through a low temperature thermolysis reaction; these are known as the metastable or kinetically stabilized hydrides. These materials have an equilibrium $\mathrm{H}_{2}$ pressure $\left(P_{\text {eq }}\right)$ much greater than 1 bar at room temperature, but do 
not decompose (or decompose very slowly) due to kinetic limitations. One of the more popular examples is ammonia borane $\left(\mathrm{NH}_{3} \mathrm{BH}_{3}\right)$, which has a total gravimetric hydrogen capacity of nearly $20 \mathrm{wt} . \%$. Although there are a number of high capacity hydrogen storage materials where the hydrogen is bound to a light main group element (e.g., $\mathrm{C}-\mathrm{H}, \mathrm{B}-\mathrm{H}, \mathrm{N}-$ $\mathrm{H}$, or $\mathrm{O}-\mathrm{H}$ ), ammonia borane is somewhat unique in that it contains both protic $(\mathrm{N}-\mathrm{H})$ and hydridic $(\mathrm{B}-\mathrm{H})$ bonds and a strong $\mathrm{B}-\mathrm{N}$ bond $[13,14]$. Although ammonia borane can be prepared in a metastable state at room temperature, it is thermodynamically unstable and can, in an ideal reaction, decompose exothermically to yield aminoborane and $\mathrm{H}_{2}$ gas. Despite the strength of the $\mathrm{B}-\mathrm{N}$ bond, the decomposition is often associated with the formation of a small amount of gaseous species such as ammonia $\left(\mathrm{NH}_{3}\right)$ or diborane $\left(\mathrm{B}_{2} \mathrm{H}_{6}\right)$. Even small quantities (a few parts-permillion) of these unwanted species is sufficient to poison a low temperature proton exchange membrane fuel cell. In recent years a number of new methods have been identified to limit these side reactions and efforts are underway to design systems equipped with scrubbers to trap these species before they reach the fuel cell. Further information on the latest developments on ammonia borane can be found in a few recent review articles [14-16].

\section{Metastable Metal Hydrides}

Similar to ammonia borane, the metastable metal hydrides offer high capacities and low temperature hydrogen release. However, unlike ammonia borane, thermal decomposition does not result in the formation of gaseous species that can degrade capacity and poison the fuel cell. Of particular interest are the aluminum-based metastable hydrides including aluminum hydride $\left(\mathrm{AlH}_{3}\right)$, lithium aluminum hydride $\left(\mathrm{LiAlH}_{4}\right.$ and $\left.\mathrm{Li}_{3} \mathrm{AlH}_{6}\right)$, magnesium aluminum hydride $\left(\mathrm{Mg}\left(\mathrm{AlH}_{4}\right)_{2}\right)$, among others. These materials exhibit a low decomposition enthalpy, which reduces the heat required to release the hydrogen at practical pressures. In addition, these materials exhibit rapid $\mathrm{H}_{2}$ evolution rates at low temperature $\left(80-100^{\circ} \mathrm{C}\right)$, due to the large driving force for decomposition.

Many of the metastable aluminum-based hydrides are ideally suited for portable power systems where weight and volume are critical. This is because the energy density of a power source consisting of a metal hydride and a PEM fuel cell is substantially larger than even the best batteries currently available as shown in Table 1 . The actual energy density of a system that utilizes $\mathrm{AlH}_{3}$ as the power source is not known (only a few small prototype systems currently exist), but based on similar systems it is reasonable to estimate a $50 \%$ penalty for weight of the tank, fuel cell, and additional hardware and an additional 50\% penalty for the fuel cell conversion efficiency. This yields a system energy density that is $25 \%$ of the material energy density. Even under this rather conservative scenario, a hydrogen fuel cell using a metal hydride (e.g., $\mathrm{AlH}_{3}$ ) as an $\mathrm{H}_{2}$ source yields gravimetric and volumetric energy densities over four times greater than even the best performing lithium polymer batteries.
TABLE 1: Comparison of hydride-fuel cell system $\left(\mathrm{AlH}_{3}+50 \mathrm{~kW}\right.$ fuel cell operating at 50\% efficiency and assuming an additional $50 \%$ energy reduction to account for the fuel cell system weight) with conventional battery systems showing the specific energy and energy density.

\begin{tabular}{lcc}
\hline Energy source & $\begin{array}{c}\text { Specific energy } \\
(\mathrm{MJ} / \mathrm{kg})\end{array}$ & $\begin{array}{c}\text { Energy density } \\
(\mathrm{MJ} / \mathrm{L})\end{array}$ \\
\hline 700 bar hydrogen tank [17] & 6.2 & 3.2 \\
350 bar hydrogen tank [17] & 6.6 & 2.1 \\
$\mathrm{AlH}_{3}$ /fuel cell & 3.1 & 4.3 \\
Li polymer & 0.72 & 1.1 \\
Ni-Metal hydride & 0.29 & 0.36 \\
Ni-Cd & 0.18 & 0.36 \\
Pb-acid & 0.11 & 0.14 \\
\hline
\end{tabular}

This spotlight paper reviews recent research efforts on the metastable metal hydrides and is specifically focused on metastable aluminum-based hydrides (alanes and alanates). This paper covers the synthesis procedures, crystal structures, thermodynamics and decomposition pathways, kinetics of hydrogen release, and regeneration efforts. A more general review on hydrogen storage, metal hydrides, and complex hydrides can be found elsewhere [46-53, 19, 20].

\section{Synthesis}

The earliest reports on the synthesis of aluminum hydride date back to the forties when Stecher and Wiberg [54] and later Finholt et al. [55] prepared alane amine and alane etherate adducts. Approximately ten years later Chizinsky et al. [56] prepared the first nonsolvated form of $\mathrm{AlH}_{3}$ using an ethereal reaction of $\mathrm{AlCl}_{3}$ with $\mathrm{LiAlH}_{4}$. In the sixties and seventies Brower et al. prepared a total of seven different polymorphs of $\mathrm{AlH}_{3}, \alpha, \alpha^{\prime}, \beta, \gamma, \delta, \varepsilon, \xi$ using a similar method [57]. The conventional synthesis method for the preparation of $\alpha-\mathrm{AlH}_{3}$ is given below:

$$
\begin{aligned}
& 4 \mathrm{LiAlH}_{4}+\mathrm{AlCl}_{3}+\mathrm{Et}_{2} \mathrm{O} \\
& \longrightarrow 4 \mathrm{AlH}_{3} \cdot n \mathrm{Et}_{2} \mathrm{O}+3 \mathrm{LiCl} \downarrow+\mathrm{LiAlH}_{4}+\mathrm{Et}_{2} \mathrm{O} \\
& 4 \mathrm{AlH}_{3} \cdot n \mathrm{Et}_{2} \mathrm{O}+\mathrm{LiAlH}_{4}+\mathrm{LiBH}_{4}+\mathrm{Et}_{2} \mathrm{O} \\
& \quad \underset{55^{\circ} \mathrm{C}}{\longrightarrow} 4 \mathrm{AlH}_{3} \downarrow+\mathrm{Et}_{2} \mathrm{O} \uparrow+\mathrm{LiAlH}_{4} \downarrow+\mathrm{LiBH}_{4} \downarrow
\end{aligned}
$$

Importantly, excess $\mathrm{LiAlH}_{4}$, and in some cases excess $\mathrm{LiBH}_{4}$, is added to the alane-ether solution to reduce the time and temperature required to remove the ether $[58,59]$. The desolvation step (reaction (3)) determines the polymorph type and particle size. In the final step, the excess $\mathrm{LiAlH}_{4}$ and $\mathrm{LiBH}_{4}$ is removed by a wash with diethyl ether $\left(\mathrm{AlH}_{3}\right.$ is insoluble in $\mathrm{Et}_{2} \mathrm{O}$ ) and, in some cases, a wash in dilute hydrochloric acid. Aluminum hydride (etherated or pure) can also be synthesized using any of the binary hydrides or tetrahydroaluminates (alanates) from the 1st and 2 nd groups 
through a reaction with a Brønsted-Lewis acid (e.g., $\mathrm{AlCl}_{3}$ ) [58, 60-67].

A variety of routes can be used to synthesize the complex aluminum hydrides. The most stable alanates (e.g., $\mathrm{KAlH}_{4}, \mathrm{NaAlH}_{4}$, and $\mathrm{NaLiAlH}_{4}$ ), also known as the reversible alanates, can be synthesized by direct hydrogenation of aluminum and the binary hydride $[9,68-70]$ :

$$
\mathrm{NaH}+\mathrm{Al}+\frac{3}{2} \mathrm{H}_{2} \stackrel{\mathrm{THF}}{\longrightarrow} \mathrm{NaAlH}_{4}
$$

The metastable alanates are not easily formed by direct hydrogenation under reasonable pressures and are typically prepared through solution methods. Probably the most common method for the preparation of these materials is a reaction of a binary hydride with a metal halide to form an alanate, as shown below $[32,66,71,72]$ :

$$
\begin{gathered}
4 \mathrm{LiH}+\mathrm{AlCl}_{3} \stackrel{\mathrm{Et}_{2} \mathrm{O}}{\longrightarrow} \mathrm{LiAlH}_{4}+3 \mathrm{LiC} \\
4 \mathrm{CaH}_{2}+2 \mathrm{AlCl}_{3} \stackrel{\mathrm{THF}}{\longrightarrow} \mathrm{Ca}\left(\mathrm{AlH}_{4}\right)_{2}+3 \mathrm{CaCl}_{2}
\end{gathered}
$$

A similar approach involves a metathesis reaction of a metal halide $\left(\mathrm{MgCl}_{2}\right)$ and an alanate $\left(\mathrm{NaAlH}_{4}\right)$ to form the metastable alanate $\left(\mathrm{Mg}\left(\mathrm{AlH}_{4}\right)_{2}\right)[35,69,73,74]$ :

$$
\begin{gathered}
\mathrm{NaAlH}_{4}+\mathrm{LiCl} \stackrel{\mathrm{Et}_{2} \mathrm{O}}{\longrightarrow} \mathrm{LiAlH}_{4}+3 \mathrm{LiCl} \\
2 \mathrm{NaAlH}_{4}+\mathrm{MgCl}_{2} \stackrel{\mathrm{DEE}}{\longrightarrow} \mathrm{Mg}\left(\mathrm{AlH}_{4}\right)_{2}+2 \mathrm{NaCl}
\end{gathered}
$$

However, these procedures are energetically and economically costly since the expensive alkali metals (e.g., $\mathrm{Na}$ ) form stable salt (e.g., $\mathrm{NaCl}$ ) byproducts, which are difficult to separate. Interestingly, many alanates can be prepared directly from $\mathrm{AlH}_{3}$ and a binary metal hydride in a chemical or mechanochemical reaction $[75,76]$, such as:

$$
\mathrm{CaH}_{2}+2 \mathrm{AlH}_{3} \longrightarrow \mathrm{Ca}\left(\mathrm{AlH}_{4}\right)_{2}
$$

\section{Crystal Structures}

The thermodynamic stability of the hydride is determined by its structure and composition. The lightweight aluminumbased hydrides can exist as pure aluminum hydride $\left(\mathrm{AlH}_{3}\right)$, a covalently bonded solid, or as a complex hydride consisting of a covalently bonded anion (e.g., $\left[\mathrm{AlH}_{6}\right]^{3-}$ or $\left[\mathrm{AlH}_{4}\right]^{-}$) and a cation. Pure aluminum hydride comes in a variety of polymorphs $\left(\alpha, \alpha^{\prime}, \beta, \gamma\right)$, all of which are metastable at room temperature [18-28]. The crystal structure of $\alpha$ $\mathrm{AlH}_{3}$ is trigonal $(R \overline{3} c$ space group) and consists of corner connected $\mathrm{AlH}_{6}$ octahedra with each $\mathrm{H}$ bridging two octahedra as shown in Figure 2 (left). The complex aluminum hydrides tend to be more stable since the complex anion is stabilized by a cation, typically an alkali (e.g., $\mathrm{Li}, \mathrm{Na}$, K) $[9,29-31,33,34,36,70]$, or alkaline earth metal (e.g., $\mathrm{Mg}, \mathrm{Ca})[35,37,38,40,74]$, or a transition metal (e.g., $\mathrm{Ti}, \mathrm{Fe})[32,39,77]$. The complex aluminum hydrides typically appear in two forms, the tetrahydroaluminates $\left(\mathrm{M}^{n+}\left(\mathrm{AlH}_{4}\right)_{n}\right)$, where $\mathrm{Al}$ is tetrahedrally coordinated by $\mathrm{H}$, and hexahydroaluminates $\left(\mathrm{M}_{3} \mathrm{AlH}_{6}, \mathrm{MAlH}_{5}, \mathrm{M}_{2} \mathrm{AlH}_{7}\right)$,

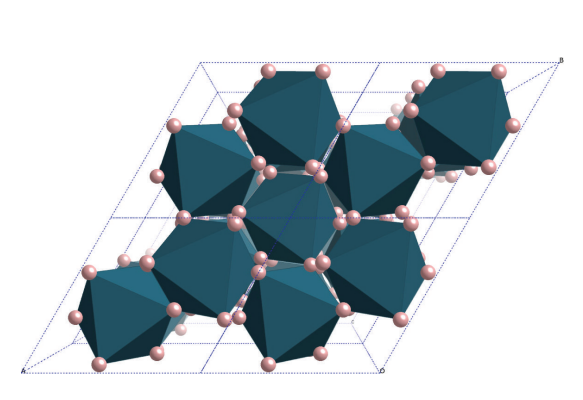

$\alpha-\mathrm{ALH}_{3}[001]$

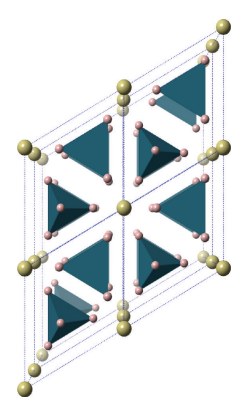

$\operatorname{Mg}\left(\mathrm{AlH}_{4}\right)_{2}[001]$
FIGURE 2: Crystal structures of alpha aluminum hydride $\left(\alpha-\mathrm{AlH}_{3}\right)$, showing $\mathrm{AlH}_{6}$ octahedra, and magnesium alanate $\left(\mathrm{Mg}\left(\mathrm{AlH}_{4}\right)_{2}\right)$ showing $\left[\mathrm{AlH}_{4}\right]^{-}$tetrahedra and $\mathrm{Mg}^{+}$cation (yellow) viewed along the [001] direction $[18,77]$.

where $\mathrm{Al}$ is octahedrally coordinated by $\mathrm{H}$. The crystal structure of $\mathrm{Mg}\left(\mathrm{AlH}_{4}\right)_{2}$, a tetrahydroaluminate, is shown in Figure 2 (right). $\operatorname{Mg}\left(\mathrm{AlH}_{4}\right)_{2}$ crystalizes in the $\mathrm{P} \overline{3} \mathrm{~m} 1$ space group and consists of $\mathrm{AlH}_{4}$ tetrahedra forming a close-pack double layer separated by a layer of $\mathrm{Mg}$ atoms [44]. A list of some lightweight metastable aluminum hydrides is shown in Table 2 along with their theoretical hydrogen content and decomposition temperature. A more thorough review of these materials and their hydrogen storage properties can be found in a few recent review articles $[28,41,78]$.

\section{Thermodynamics and Decomposition Pathways}

The decomposition thermodynamics, or more specifically, the free energy difference between the reactant and the product, determines the $\mathrm{H}_{2}$ equilibrium pressure at a given temperature. For binary hydrides (e.g., $\mathrm{AlH}_{3}$ ) the decomposition pathway is a single step (to the elements) and the decomposition enthalpy is the negative of the formation enthalpy. Differential scanning calorimetry (DSC) plots from $\alpha-, \beta-$, and $\gamma-\mathrm{AlH}_{3}$ undergoing thermal decomposition (temperature ramp from 35 to $300^{\circ} \mathrm{C}$ ) are shown in Figure 2. The DSC trace from $\alpha-\mathrm{AlH}_{3}$ exhibits a single endothermic peak at around $170^{\circ} \mathrm{C}$ and is attributed to the decomposition of $\alpha-\mathrm{AlH}_{3}$ :

$$
\alpha-\mathrm{AlH}_{3} \rightarrow \mathrm{Al}+\frac{3}{2} \mathrm{H}_{2}
$$

Although the endothermic peak occurs at $170^{\circ} \mathrm{C}, \alpha$ $\mathrm{AlH}_{3}$ will decompose slowly at lower temperatures (complete decomposition in $\sim 10 \mathrm{hrs}$ at $100^{\circ} \mathrm{C}$ ) [19]. Experimentally determined (calorimetry) values for the formation enthalpy of $\alpha-\mathrm{AlH}_{3}$ range from -6.0 to $-7.6 \mathrm{~kJ} / \mathrm{mol} \mathrm{H}_{2}[20,45,79]$, with a formation entropy of $20 \mathrm{~J} / \mathrm{K} \mathrm{mol} \mathrm{H}_{2}$ [44]. Based on these values the Gibbs formation energy for $\alpha-\mathrm{AlH}_{3}$ at $300 \mathrm{~K}$ is approximately $31 \mathrm{~kJ} / \mathrm{mol} \mathrm{H}_{2}[20,44]$. The DSC plots from $\beta-\mathrm{AlH}_{3}$ and $\gamma-\mathrm{AlH}_{3}$ are also shown in Figure 3. In addition to the endothermic decomposition peak at $170^{\circ} \mathrm{C}$, there are distinct exothermic peaks at approximately $100^{\circ} \mathrm{C}$ for both polymorphs. A similar exothermic peak was observed during decomposition of $\alpha^{\prime}-\mathrm{AlH}_{3}$ [80]. These peaks are due 
TABLE 2: A few examples of unstable and metastable aluminum-based hydrides showing hydrogen weight percent and the initial decomposition temperature (in many cases full hydrogen desorption occurs over multiple steps that occur at higher temperatures). It is also worth noting that the decomposition temperatures listed identify the temperature at which significant $\mathrm{H}_{2}$ evolution occurs and may be lower than the exothermic or endothermic peaks observed in calorimetric measurements.

\begin{tabular}{|c|c|c|c|c|c|}
\hline Alanes and hexahydride alanates & Wt.\%H & Decomposition temperature & Tetrahydride alanates & Wt.\%H & Decomposition temperature \\
\hline$\alpha-\mathrm{AlH}_{3}[18-28]$ & 10.1 & $100^{\circ} \mathrm{C}$ & $\mathrm{LiAlH}_{4}[29-31]$ & 10.5 & $120^{\circ} \mathrm{C}$ \\
\hline$\alpha^{\prime}-\mathrm{AlH}_{3}[21]$ & 10.1 & $90^{\circ} \mathrm{C}$ & $\mathrm{CuAlH}_{4}[32]$ & & $-70^{\circ} \mathrm{C}$ \\
\hline$\beta-\mathrm{AlH}_{3}[19,20,22]$ & 10.1 & $80^{\circ} \mathrm{C}$ & $\mathrm{AgAlH}_{4}[32]$ & & $-50^{\circ} \mathrm{C}$ \\
\hline$\gamma-\mathrm{AlH}_{3}[19,20,23-28]$ & 10.1 & $80^{\circ} \mathrm{C}$ & $\mathrm{Be}\left(\mathrm{AlH}_{4}\right)_{2}[32]$ & & $20^{\circ} \mathrm{C}$ \\
\hline \multirow[t]{10}{*}{$\mathrm{Li}_{3} \mathrm{AlH}_{6}[29-31,33,34]$} & 11.1 & $160^{\circ} \mathrm{C}$ & $\operatorname{Mg}\left(\mathrm{AlH}_{4}\right)_{2}[35,36]$ & & $110^{\circ} \mathrm{C}$ \\
\hline & & & $\mathrm{Ca}\left(\mathrm{AlH}_{4}\right)_{2}[37,38]$ & & $150^{\circ} \mathrm{C}$ \\
\hline & & & $\operatorname{Mn}\left(\mathrm{AlH}_{4}\right)_{2}[32]$ & & $25^{\circ} \mathrm{C}$ \\
\hline & & & $\mathrm{Fe}\left(\mathrm{AlH}_{4}\right)_{2}[32,39]$ & & $<-45^{\circ} \mathrm{C}$ \\
\hline & & & $\operatorname{LiMg}\left(\mathrm{AlH}_{4}\right)_{3}[37]$ & & $100^{\circ} \mathrm{C}$ \\
\hline & & & $\mathrm{CaMg}\left(\mathrm{AlH}_{4}\right)_{3}[38]$ & & $125^{\circ} \mathrm{C}$ \\
\hline & & & $\operatorname{In}\left(\mathrm{AlH}_{4}\right)_{3}[32]$ & & $-40^{\circ} \mathrm{C}$ \\
\hline & & & $\mathrm{Ce}\left(\mathrm{AlH}_{4}\right)_{3}[32]$ & & $25^{\circ} \mathrm{C}$ \\
\hline & & & $\mathrm{Ti}\left(\mathrm{AlH}_{4}\right)_{4}[32,40]$ & & $-85^{\circ} \mathrm{C}$ \\
\hline & & & $\mathrm{Sn}\left(\mathrm{AlH}_{4}\right)_{4}[32]$ & & $-40^{\circ} \mathrm{C}$ \\
\hline
\end{tabular}

to a polymorphic transition (no $\mathrm{H}_{2}$ release) from the less stable phase $\left(\alpha^{\prime}, \beta, \gamma\right)$ to the more stable $\alpha$ phase. The energies of the polymorph transitions are $-1.1 \mathrm{~kJ} / \mathrm{mol} \mathrm{\textrm {H } _ { 2 }}$ $\left(\alpha^{\prime}-\mathrm{AlH}_{3} \rightarrow \alpha-\mathrm{AlH}_{3}\right),-1.0 \mathrm{~kJ} / \mathrm{mol} \mathrm{H}_{2}\left(\beta-\mathrm{AlH}_{3} \rightarrow \alpha-\right.$ $\left.\mathrm{AlH}_{3}\right)$, and $-1.9 \mathrm{~kJ} / \mathrm{mol} \mathrm{H}_{2}\left(\gamma-\mathrm{AlH}_{3} \rightarrow \alpha-\mathrm{AlH}_{3}\right)[20,79]$. Subsequent studies have shown that at higher temperature $\left(>100^{\circ} \mathrm{C}\right)$ the decomposition of the less stable polymorphs occurs by a polymorphic transition to the $\alpha$ phase followed by $\mathrm{H}_{2}$ release $[25,28]$. At lower temperatures the decomposition is more complex with a fraction of the material decomposing directly to the elements (e.g., $\gamma-\mathrm{AlH}_{3} \rightarrow \mathrm{Al}+$ $3 / 2 \mathrm{H}_{2}$ ) while the remaining material transforms to $\alpha-\mathrm{AlH}_{3}$ before decomposing (e.g., $\gamma-\mathrm{AlH}_{3} \rightarrow \alpha-\mathrm{AlH}_{3} \rightarrow \mathrm{Al}+$ $3 / 2 \mathrm{H}_{2}$ ).

The decomposition pathways for the complex metal hydrides are not always as simple as those of the binary hydrides. For example, the group 1 tetrahydroaluminates (e.g., $\mathrm{LiAlH}_{4}$ ) typically decompose to a hexahydridoaluminate first, then to a binary hydride (and $\mathrm{Al}$ ), and finally to the alloy ( $\mathrm{LiAl})[31,43]$, as shown below:

$$
\begin{aligned}
& \mathrm{LiAlH}_{4} \stackrel{150^{\circ} \mathrm{C}}{\longrightarrow} \frac{1}{3}\left(\mathrm{Li}_{3} \mathrm{AlH}_{6}\right)+\frac{2}{3} \mathrm{Al}+\mathrm{H}_{2} \\
& \stackrel{200^{\circ} \mathrm{C}}{\longrightarrow} \mathrm{LiH}+\mathrm{Al}+\frac{3}{2} \mathrm{H}_{2} \stackrel{450^{\circ} \mathrm{C}}{\longrightarrow} \mathrm{LiAl}+2 \mathrm{H}_{2}
\end{aligned}
$$

Tomiyasu et al. recently showed that in the case of $\mathrm{LiAlH}_{4}$, the decomposition stems from a lattice instability attributed to the weak of binding of the complex anions in the lattice [81].

For the metastable hydrides, the decomposition can be exothermic or weakly endothermic. Figure 4 shows the DSC traces from three metastable hydrides $\left(\mathrm{LiAlH}_{4}, \mathrm{Ca}\left(\mathrm{AlH}_{4}\right)_{2}\right.$, and $\left.\mathrm{Mg}\left(\mathrm{AlH}_{4}\right)_{2}\right)$ during thermal decomposition. At each stage of the reaction the material releases some hydrogen and undergoes a structural transition to a more stable phase. The $\operatorname{Mg}\left(\mathrm{AlH}_{4}\right)_{2}$ phase undergoes a slightly endothermic

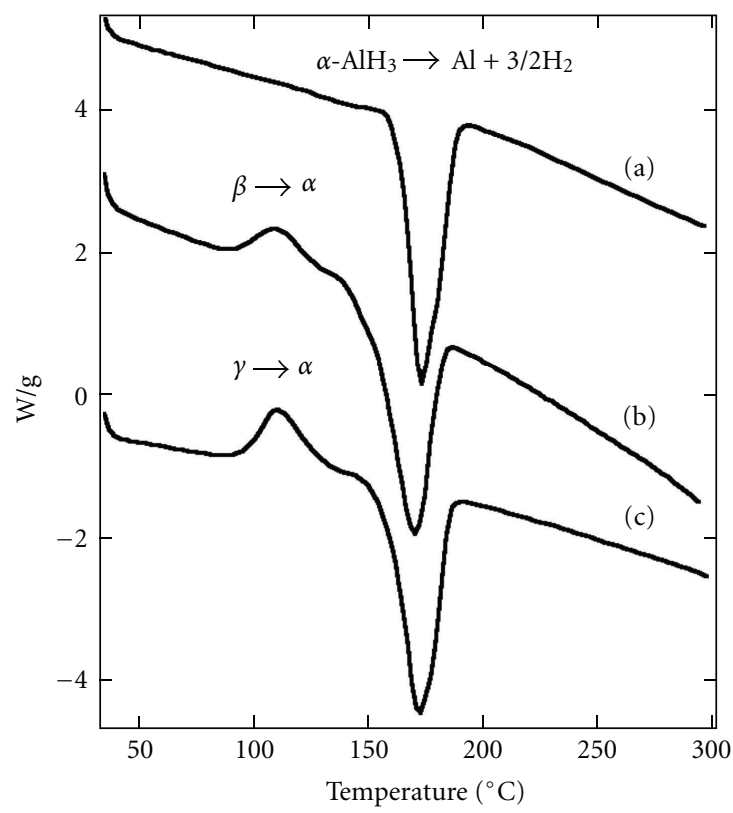

Figure 3: DSC traces $\left(10^{\circ} \mathrm{C} / \mathrm{min}\right)$ from (a) $\alpha-\mathrm{AlH}_{3}$, (b) $\beta-\mathrm{AlH}_{3}$, and (c) $\gamma-\mathrm{AlH}_{3}$ showing the exothermic polymorphic transition at $\sim 100^{\circ} \mathrm{C}$ and the endothermic decomposition at $\sim 170^{\circ} \mathrm{C}[20]$.

transition $(\Delta H=1.7-5.5 \mathrm{~kJ} / \mathrm{mol})$ at $\sim 110^{\circ} \mathrm{C}$ directly to the binary hydride $\left(\mathrm{MgH}_{2}\right)$ and $\mathrm{Al}[37,42,82]$ :

$$
\mathrm{Mg}\left(\mathrm{AlH}_{4}\right)_{2} \stackrel{110^{\circ} \mathrm{C}}{\longrightarrow} \mathrm{MgH}_{2}+2 \mathrm{Al}+3 \mathrm{H}_{2}
$$

The first decomposition step of $\mathrm{Ca}\left(\mathrm{AlH}_{4}\right)_{2}$ is exothermic and occurs at $\sim 150^{\circ} \mathrm{C}[37,38,81,83]$ :

$$
\mathrm{Ca}\left(\mathrm{AlH}_{4}\right)_{2} \stackrel{100^{\circ} \mathrm{C}}{\longrightarrow} \mathrm{CaAlH}_{5}+\mathrm{Al}+\frac{3}{2} \mathrm{H}_{2}
$$




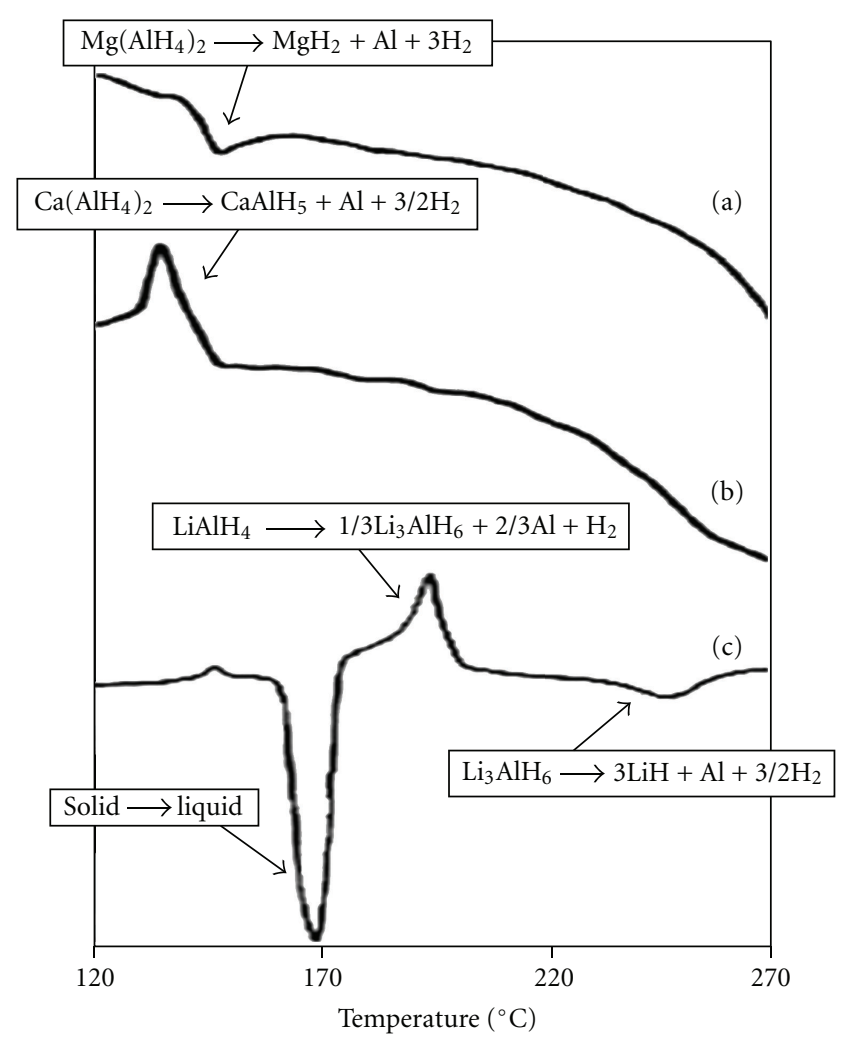

Figure 4: DSC traces $\left(5^{\circ} \mathrm{C} / \mathrm{min}\right)$ from (a) $\mathrm{Mg}\left(\mathrm{AlH}_{4}\right)_{2}$ [33], (b) $\mathrm{Ca}\left(\mathrm{AlH}_{4}\right)_{2}$ [33], and (c) $\mathrm{LiAlH}_{4}$ [27] showing exothermic (positive peaks) and endothermic (negative peaks) transitions.

The decomposition enthalpy of this step is $-7.4 \mathrm{~kJ} / \mathrm{mol}$. Unlike $\mathrm{Mg}\left(\mathrm{AlH}_{4}\right)_{2}$, the $\mathrm{Ca}\left(\mathrm{AlH}_{4}\right)_{2}$ decomposes to a pentahydride phase, before undergoing a more endothermic transition to the binary hydride at higher temperatures.

The decomposition of $\mathrm{LiAlH}_{4}$ occurs by a three-step reaction first to the hexahydridoaluminate $\left(\mathrm{Li}_{3} \mathrm{AlH}_{6}\right)$, then to $\mathrm{LiH}$ and $\mathrm{Al}$, and finally to the elements $\mathrm{Li}$ and $\mathrm{Al}$ (reaction (10)). The DSC trace at the bottom of Figure 4 shows a slight exothermic peak at $150^{\circ} \mathrm{C}$, which is attributed to a reaction with hydroxyl groups on the surface. The first endothermic minimum at $\sim 170^{\circ} \mathrm{C}$ is due to melting $[29,33]$, which is immediately followed by the exothermic decomposition $\left(175-220^{\circ} \mathrm{C}\right)$ of liquid $\mathrm{LiAlH}_{4}$ to the solid $\mathrm{Li}_{3} \mathrm{AlH}_{6}$. Although considerably more reactive in the liquid state, solid $\mathrm{LiAlH}_{4}$ is metastable and can spontaneously decompose slowly at room temperature [84]. $\mathrm{LiAlH}_{4}$ exhibits a large, negative formation enthalpy $(-94 \mathrm{~kJ} / \mathrm{mol})$ [42], making it stable against decomposition to the elements; however, $\mathrm{LiAlH}_{4}$ is thermodynamically unstable against decomposition to the hexahydroaluminate phase (step 1 of reaction (10)) [33]. The higher temperature endotherm in the DSC trace $\left(240^{\circ} \mathrm{C}\right)$ is attributed to the decomposition of $\mathrm{Li}_{3} \mathrm{AlH}_{6}$ to $\mathrm{LiH}$ and $\mathrm{Al}$ (step 2 of reaction (10)) [30, 33]. The final decomposition step is the endothermic hydrogen release from $\mathrm{LiH}$ (step 3 of reaction (10)), which occurs at much higher temperatures $\left(>450^{\circ} \mathrm{C}\right)$.

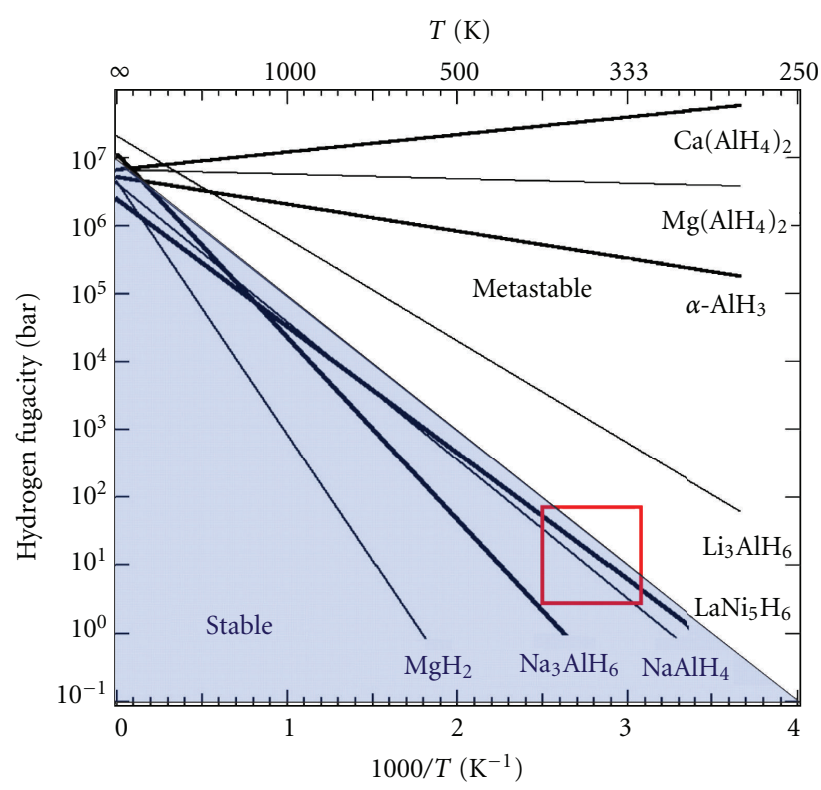

Figure 5: Approximate van't Hoff plots for several reversible and nonreversible hydrides $[20,37,43,44,83,84]$. The compounds in the lower left (shaded) region are stable while the compounds in the upper right are unstable or metastable at ambient pressure and temperature. The box represents the thermodynamic target for "onboard reversible" hydrides. Reproduced by permission of The Royal Society of Chemistry [94].

A list of decomposition reactions, along with the amount of $\mathrm{H}_{2}$ released and the reaction enthalpy $(\Delta H)$, is shown in Table 3. A plot of the calculated equilibrium pressure as a function of temperature (van't Hoff plot) for several metastable hydrides is shown in Figure 5 [20, 37, 43, 44, 85, 86]. It is important to note that the values used in Figure 5 correspond to $\mathrm{H}_{2}$ fugacities, not hydrogen pressures. If $\mathrm{H}_{2}$ is treated strictly as an ideal gas, a reasonable approximation at low pressures $(<300 \mathrm{bar})$, then the hydrogen pressure is roughly equivalent to the hydrogen fugacity. However, at higher pressures the thermodynamic activity of $\mathrm{H}_{2}$ is considerably higher than what is expected from an ideal gas $[87,88]$. The fugacity-to-pressure ratio for $\mathrm{H}_{2}$ gas is $\sim 1$ at 1 bar, $\sim 2$ at $1 \mathrm{kbar}$, and $\sim 300$ at $10 \mathrm{kbar}$. Therefore, in some cases, hydrogenation occurs at much lower pressures than what is predicted from the reaction isotherm equation. In the case of $\alpha-\mathrm{AlH}_{3}$ at $300 \mathrm{~K}$ the predicted $\mathrm{H}_{2}$ fugacity is $f_{\mathrm{H}_{2}}=5 \times 10^{5}$ bar, which is equivalent to a hydrogen pressure of $7 \mathrm{kbar}$ [89], which is in reasonable agreement with high pressure hydrogenation experiments [90-93].

\section{Kinetics and $\mathrm{H}_{2}$ Rates}

The rate of $\mathrm{H}_{2}$ desorption from aluminum hydride and lithium aluminum hydride varies considerably with the properties of the material (e.g., structure, morphology/size, surface composition, and catalyst concentration). The isothermal decomposition curve typically has a similar sigmoidal shape (over a single reaction step) with three distinct regions as shown in Figure 6 for $\mathrm{AlH}_{3}$ : (i) an induction 
TABle 3: Decomposition reactions of a few metastable metal hydrides showing $\mathrm{H}_{2}$ content (wt.\%) and enthalpy $\left(\mathrm{kJ} / \mathrm{mol} \mathrm{H}_{2}\right)$. Negative enthalpy values indicate an exothermic decomposition reaction.

\begin{tabular}{lcccc}
\hline Reactant & Product & $\mathrm{H}_{2}$ content $($ wt.\% $)$ & $\Delta H\left(\mathrm{~kJ} / \mathrm{mol} \mathrm{H}_{2}\right)$ & References \\
\hline $\mathrm{LiAlH}_{4}$ & $1 / 3 \mathrm{Li}_{3} \mathrm{AlH} \mathrm{H}_{6}+2 / 3 \mathrm{Al}+\mathrm{H}_{2}$ & 5.3 & $(-9.1-)(-9.6)$ & {$[41,42]$} \\
$\mathrm{Li}_{3} \mathrm{AlH}_{6}$ & $3 \mathrm{LiH}+\mathrm{Al}+3 / 2 \mathrm{H}_{2}$ & 5.6 & $27-29$ & {$[33,41]$} \\
$\mathrm{Mg}\left(\mathrm{AlH}_{4}\right)_{2}$ & $\mathrm{MgH}_{2}+2 \mathrm{Al}+3 \mathrm{H}_{2}$ & 7.0 & 1.8 & {$[37,43]$} \\
$\mathrm{Ca}\left(\mathrm{AlH}_{4}\right)_{2}$ & $\mathrm{CaAlH}_{5}+\mathrm{A}+3 / 2 \mathrm{H}_{2}$ & 2.9 & -7.4 & {$[37]$} \\
$\mathrm{LiMg}\left(\mathrm{AlH}_{4}\right)_{3}$ & $\mathrm{LiMgAlH}_{6}+2 \mathrm{Al}+3 \mathrm{H}_{2}$ & 4.8 & -15 & {$[37]$} \\
$\alpha-\mathrm{AlH}_{3}$ & $\mathrm{Al}+3 / 2 \mathrm{H}_{2}$ & 10 & $6.0-7.6$ & {$[20,44,45]$} \\
$\beta-\mathrm{AlH}_{3}$ & $\mathrm{Al}+3 / 2 \mathrm{H}_{2}$ & 10 & 5.3 & {$[20]$} \\
$\gamma-\mathrm{AlH}_{3}$ & $\mathrm{Al}+3 / 2 \mathrm{H}_{2}$ & 10 & 4.7 & {$[20]$} \\
\hline
\end{tabular}

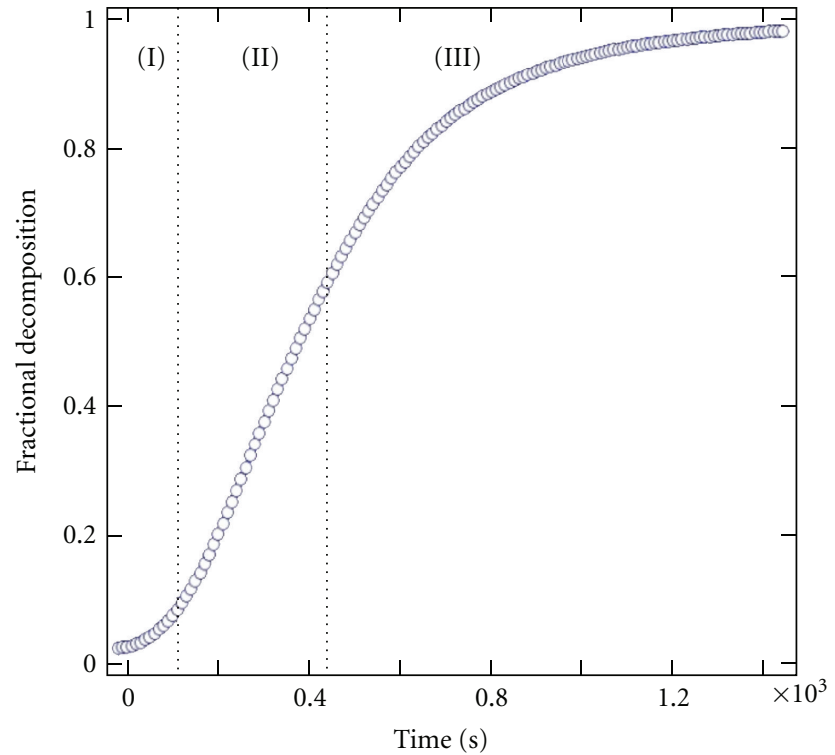

FIgURE 6: Isothermal decomposition of $\alpha-\mathrm{AlH}_{3}$ (prepared by Dow Chemical Co.) at $180^{\circ} \mathrm{C}$ showing (I) induction period, (II) acceleratory period, and (III) decay period [28].

period at the onset of the reaction, corresponding to a breakup of the surface layer and nucleation of aluminum; (ii) an acceleratory period, attributed to growth of the aluminum phase in two and three dimensions; (iii) a decay period, where the concentration of the hydride phase is limited and the growing aluminum particles begin to overlap [28].

Isothermal $\mathrm{H}_{2}$ evolution rates (based on $100 \mathrm{~kg}$ of material) for the metastable metal hydrides $\alpha-\mathrm{AlH}_{3}$ and $\mathrm{LiAlH}_{4}$ (first step only) and catalyzed and uncatalyzed $\mathrm{NaAlH}_{4}$ (first step only) are shown in Figure 7 [19, 30, 95]. The high hydrogen evolution rates at low temperature are clearly evident in the plot. At $120^{\circ} \mathrm{C}$ the $\mathrm{H}_{2}$ evolution rate from $\mathrm{LiAlH}_{4}$ (first part of reaction (10)) is 100 times greater than that of $\mathrm{NaAlH}_{4}$ (uncatalyzed). The decomposition of $\mathrm{Li}_{3} \mathrm{AlH}_{6}$ in the second step (second part of reaction (10)) also occurs rapidly at low temperature $\left(120-140^{\circ} \mathrm{C}\right)$ [30]. The activation energies for the two-step decomposition of $\mathrm{LiAlH}_{4}$ are $82 \mathrm{~kJ} / \mathrm{mol}$ (first part of reaction (10)) and $90-100 \mathrm{~kJ} / \mathrm{mol}$ (second part of reaction (10)) $[30,96]$. The kinetic studies

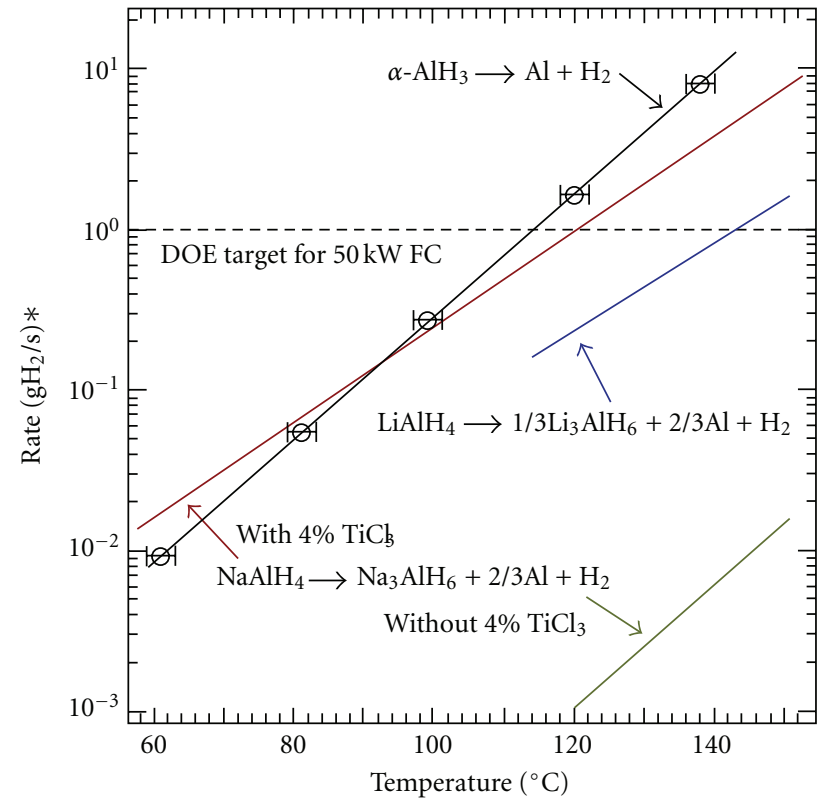

Figure 7: Hydrogen evolution rates (based on $100 \mathrm{~kg}$ of material) for the metastable metal hydrides $\alpha-\mathrm{AlH}_{3}$ and $\mathrm{LiAlH}_{4}$ (first step only) compared to catalyzed and uncatalyzed $\mathrm{NaAlH}_{4}$ (first step only) $[19,30,93]$. The dotted line shows the US Department of Energy (DOE) $\mathrm{H}_{2}$ rate target for a $50 \mathrm{~kW}$ fuel cell $\left(1 \mathrm{gH}_{2} / \mathrm{s}\right)$.

of Andreasen et al. suggest that the decomposition of the tetrahydride is limited by long-range metal transport [30], similar to the $\mathrm{NaAlH}_{4}$ system $[93,97]$.

In the case of $\mathrm{LiAlH}_{4}$, low temperature $\left(<250^{\circ} \mathrm{C}\right)$ dehydrogenation occurs over two distinct reaction steps (see reaction (10)). Over the past 10 years there has been considerable interest in identifying catalysts to enhance the low temperature desorption rates and/or decrease the desorption temperature. A significant reduction in decomposition temperature has been achieved using a variety of additives including $\mathrm{TiF}_{3}$ [98], $\mathrm{TiCl}_{3}$ [99], $\mathrm{TiCl}_{3} \cdot 1 / 3 \mathrm{AlCl}_{3}[100,101]$, $\mathrm{VCl}_{3}[99,102], \mathrm{LaCl}_{3}[103], \mathrm{NbF}_{5}[104], \mathrm{VBr}_{3}[100], \mathrm{AlCl}_{3}$ [100], $\mathrm{NiCl}_{2}$ [105], nanoscale $\mathrm{Fe}$ and $\mathrm{Ni}[80,106]$, TiC [100], and carbon fibers [107]. As an example we can compare the activation energy for the first decomposition step $\left(3 \mathrm{LiAlH}_{4} \rightarrow \mathrm{Li}_{3} \mathrm{AlH}_{6}+2 \mathrm{Al}+3 \mathrm{H}_{2}\right)$, which is typically around $102 \mathrm{~kJ} / \mathrm{mol}$ for the uncatalyzed material $[99,105]$. 


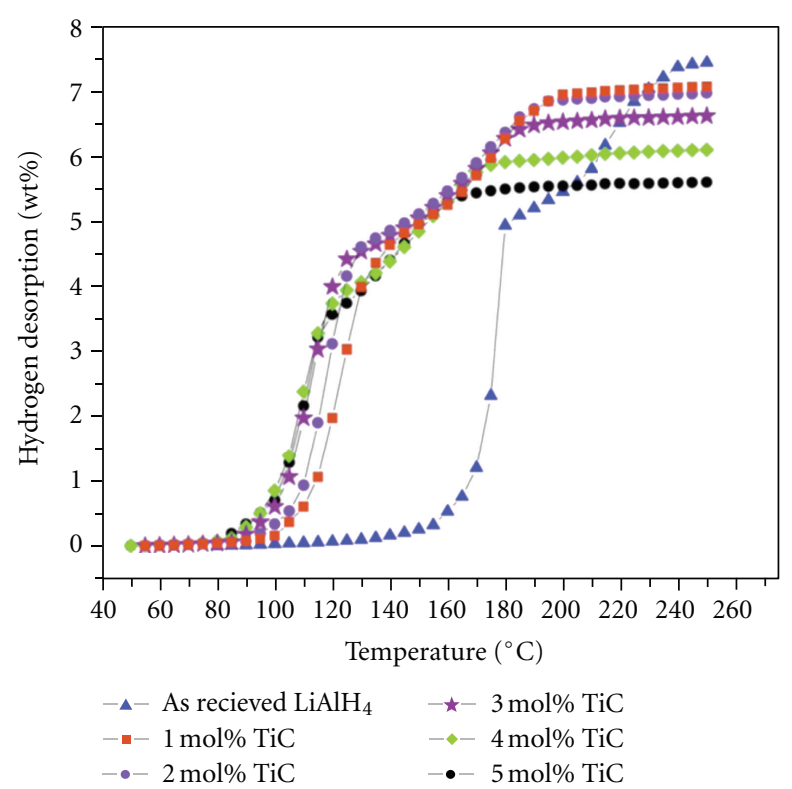

FIgure 8: Thermal desorption profiles of as-received $\mathrm{LiAlH}_{4}$ and $\mathrm{LiAlH}_{4}$ catalyzed with $1-5 \mathrm{~mol} \% \mathrm{TiC}$ at a heating rate of $4^{\circ} \mathrm{C} / \mathrm{min}$ up to $250^{\circ} \mathrm{C}$. Reproduced by permission of Elsevier [105].

The activation energy is reduced to $\sim 95 \mathrm{~kJ} / \mathrm{mol}$ with the addition of $2 \mathrm{~mol} \% \mathrm{TiCl}_{3} \cdot 1 / 3 \mathrm{AlCl}_{3}$ and $90 \mathrm{~kJ} / \mathrm{mol}$ with the addition of $2 \mathrm{~mol} \% \mathrm{VCl}_{3}$ (activation energies determined from decomposition of $\mathrm{LiAlD}_{4}$ ) [99]. A more substantial decrease in desorption temperature was achieved with the addition of a few mole percent of TiC (shown in Figure 8), which lowered the activation energy to $86 \mathrm{~kJ} / \mathrm{mol}$ [105]. Further reductions in the desorption temperature were recently demonstrated with the addition of $1 \mathrm{~mol}^{2} \mathrm{NbF}_{5}$, which lowered the activation energy to $67 \mathrm{~kJ} / \mathrm{mol}$ [102], and nanoscale iron particles, which reduced the activation energy to $55-60 \mathrm{~kJ} / \mathrm{mol}[80]$.

Similar to $\mathrm{LiAlH}_{4}$, the hydrogen evolution rates from $\mathrm{AlH}_{3}$ are rapid at low temperature. Early kinetic studies were performed by Herley and Christofferson [108] for the decomposition of the $\alpha-\mathrm{AlH}_{3}$ (stabilized form prepared by Dow Chem. Co.) and more recently by Graetz and Reilly for $\alpha$-, $\beta$-, and $\gamma-\mathrm{AlH}_{3}$ [19]. At $120^{\circ} \mathrm{C}$ the $\mathrm{H}_{2}$ evolution rate from $\alpha-\mathrm{AlH}_{3}$ is $\sim 2 \mathrm{gH}_{2} / \mathrm{s}$, based on $100 \mathrm{~kg}$ of material. This rate is more than 1000 times greater than that of $\mathrm{NaAlH}_{4}$ (uncatalyzed) and exceeds the full flow target of $1 \mathrm{gH}_{2} / \mathrm{s}$ for a $50 \mathrm{~kW}$ fuel cell. The early studies by Rafi-UdDin et al. on a stabilized form of $\alpha-\mathrm{AlH}_{3}$, prepared by the Dow Chemical Company, revealed an activation energy of $\sim 150 \mathrm{~kJ} / \mathrm{mol}$ [109]. However, more recent studies on freshly synthesized $\alpha-\mathrm{AlH}_{3}$, without the stabilizing coating, gave an activation energy of $\sim 102 \mathrm{~kJ} / \mathrm{mol}$ for the same polymorph [19]. In both cases, the isothermal decomposition curves from both stabilized and unstabilized $\alpha-\mathrm{AlH}_{3}$ were found to obey Avrami-Erofeev kinetics, suggesting that desorption rates are limited by nucleation and growth of the $\mathrm{Al}$ phase $[19,109]$.
At high temperatures $\left(>100^{\circ} \mathrm{C}\right)$ all three $\mathrm{AlH}_{3}$ polymorphs exhibit similar decomposition rates. The less stable $\gamma$ and $\beta$ phases quickly transform to the $\alpha$ phase before decomposing to the elements [20] and the $\mathrm{H}_{2}$ evolution rates are essentially governed by the decomposition of the $\alpha$ phase. Below $100^{\circ} \mathrm{C}$ there is a clear splitting of the kinetic plot with much faster $\mathrm{H}_{2}$ rates occurring in the $\gamma$ and $\beta$ phases. As previously mentioned, at the lower temperatures the less stable polymorphs $\left(\alpha^{\prime}, \beta\right.$ and $\left.\gamma\right)$ undergo some direct decomposition to $\mathrm{Al}+3 / 2 \mathrm{H}_{2}$ without transforming to the $\alpha$ phase. Therefore, these phases $\left(\alpha^{\prime}, \beta\right.$ and $\left.\gamma\right)$ will likely be too unstable for many applications (e.g., automotive) that require material stability at temperatures up to $50^{\circ} \mathrm{C}$. However, there may be alternative applications for these materials, where a slow, steady hydrogen release is required at room temperature.

A suitable hydrogen storage material must not only exhibit rapid $\mathrm{H}_{2}$ rates at low temperature, but also a controllable decomposition. Isothermal and intermittent isothermal decomposition from $\alpha-\mathrm{AlH}_{3}$ (Figure 9) shows the total $\mathrm{H}_{2}$ evolved (red circles) and the first derivative of the total $\mathrm{H}_{2}$ evolved (blue line), which corresponds to the $\mathrm{H}_{2}$ rate for $100 \mathrm{~kg}$ of material. Importantly, Figure 9(b) clearly demonstrates that the $\mathrm{H}_{2}$ evolution rates can be slowed and even stopped by reducing the reactor temperature. When the reactor is heated back to the decomposition temperature $\left(120^{\circ} \mathrm{C}\right)$, the rate returns to the rate before the temperature was reduced. When the reactor is repeatedly heated and cooled, simulating a simple use or drive cycle, the general Lorentzian shape of the rate curves is similar. This suggests that the full spectrum of $\mathrm{H}_{2}$ evolution rates (e.g., 0.0$1.0 \mathrm{gH}_{2} / \mathrm{s}$ ) can likely be obtained using a metastable hydride with a variable temperature hydride bed.

For the as-prepared $\alpha-\mathrm{AlH}_{3}$, the decomposition reaction can be effectively turned "off" at approximately room temperature (Figure 9(b)). However, kinetic studies of $\mathrm{AlH}_{3}$ and other metastable hydrides have demonstrated that the stability and decomposition rates vary significantly with the material properties (e.g., crystallite size, surface coatings, and catalysts) $[28,30,31]$. The uncoated, fine crystallites $(0.1 \mu \mathrm{m})$ of $\alpha-\mathrm{AlH}_{3}$ exhibit a decomposition temperature below $60^{\circ} \mathrm{C}$ while the material composed of $50 \mu \mathrm{m}$ crystallites with an organic coating decomposes at temperatures above $130^{\circ} \mathrm{C}$ with an $\mathrm{H}_{2}$ evolution rate more than two orders of magnitude slower (Figure 10). More recently it has been demonstrated that the surface coatings play the dominant role in determining the reaction rate, while the role of crystallite size is secondary (Huang et al., unpublished data). A better understanding of the role of size and morphology will be critical for the development of a kinetically stabilized hydrogen storage system.

\section{Tank Design}

A hydrogen fuel cell system designed for a metastable metal hydride will be significantly different from conventional hydride beds. For example, systems configured for reversible metal hydrides are typically designed to operate at a constant temperature and the $\mathrm{H}_{2}$ release is controlled by pressure. As 


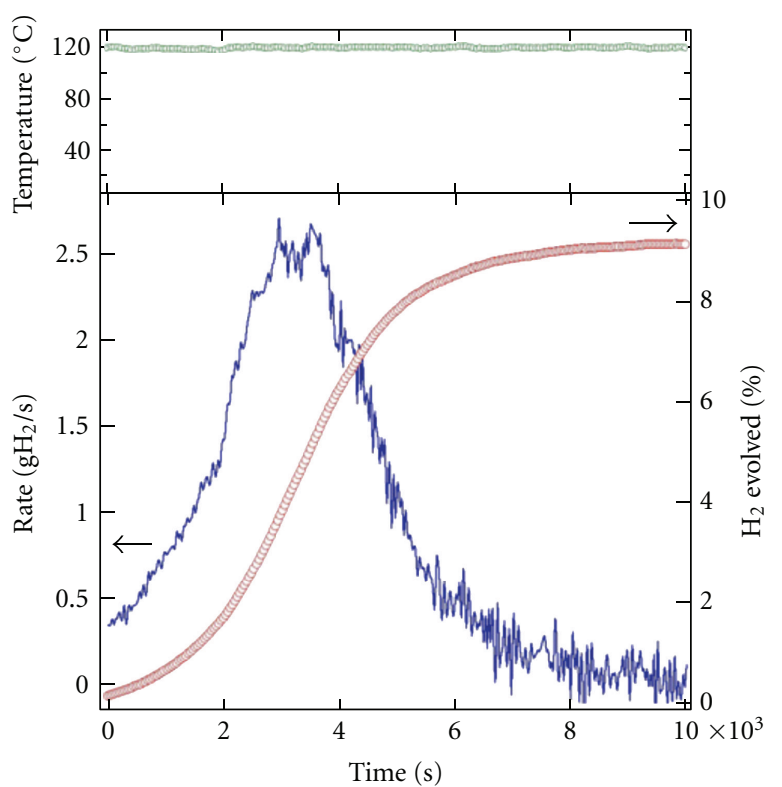

(a)

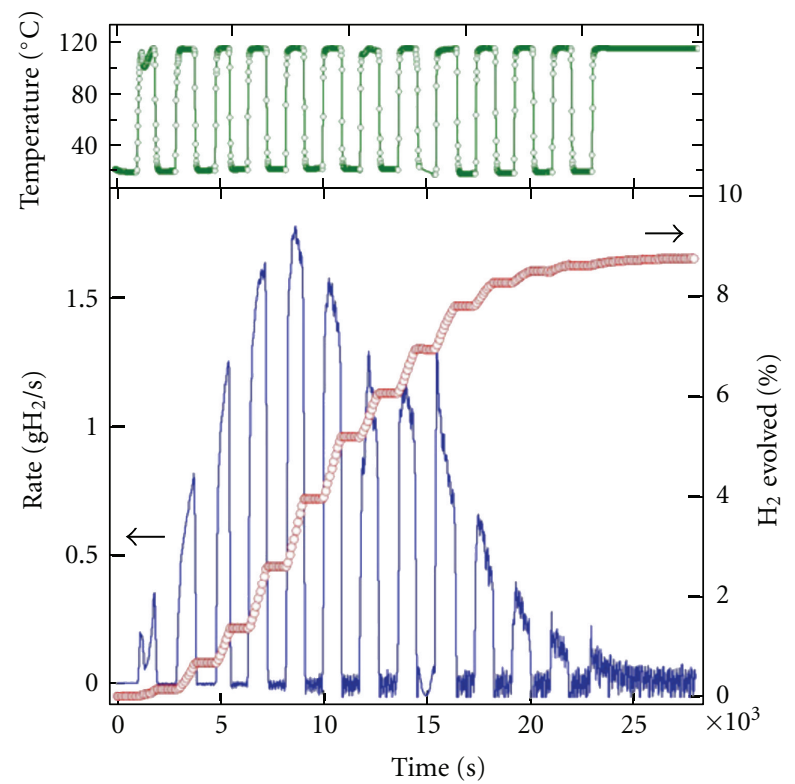

(b)

Figure 9: (a) Isothermal and (b) "on/off” decomposition at $120^{\circ} \mathrm{C}$ showing the percent $\mathrm{H}_{2}$ evolved, the rate of $\mathrm{H}_{2}$ evolution based on $100 \mathrm{~kg}$ of $\mathrm{AlH}_{3}$, and the sample temperature. Reproduced by permission of The Royal Society of Chemistry [92].

the fuel cell consumes hydrogen the pressure drops below the equilibrium pressure driving further decomposition. When the rate of $\mathrm{H}_{2}$ release exceeds the rate of consumption, the pressure rises until it reaches the equilibrium pressure. This is not the case for the metastable metal hydrides, since the equilibrium pressures are much too high to limit the decomposition. Therefore, the rate of $\mathrm{H}_{2}$ release must be kinetically controlled through the temperature. As demonstrated in Figure 9, the hydrogen release can be turned "on"

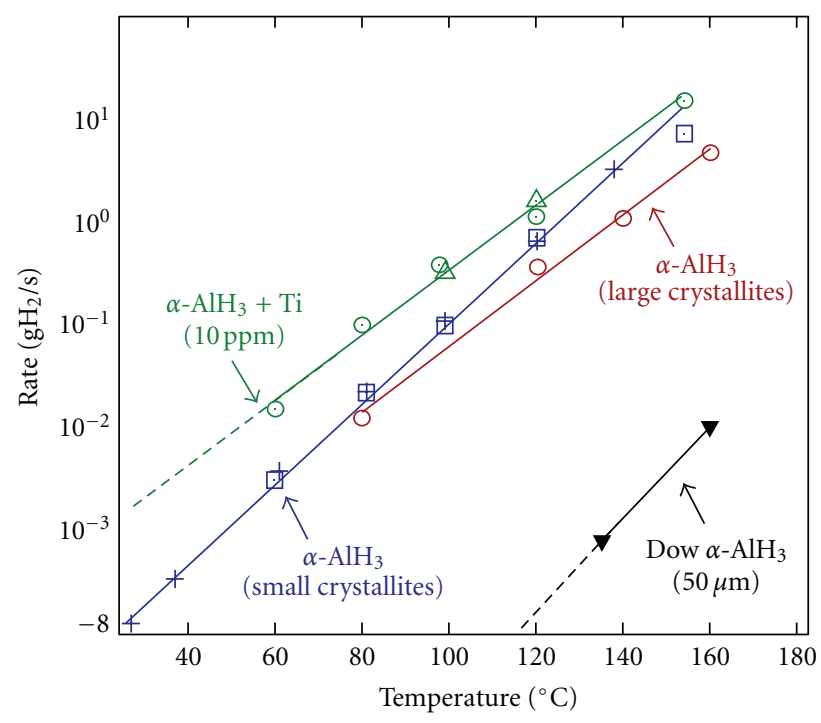

FIGURE 10: Hydrogen evolution rates as a function of temperature from pure $\alpha-\mathrm{AlH}_{3}, \alpha-\mathrm{AlH}_{3}$ prepared by ATK (uncoated), $\alpha-\mathrm{AlH}_{3}$ prepared by Dow Chemical (coated), and catalyzed $\alpha-\mathrm{AlH}_{3}$.

and "off" thermally, but this poses a number of engineering challenges. First, many applications will require a material that is completely stable at $40^{\circ} \mathrm{C}$ (e.g., when a car is parked on a hot summer day), but that same material must also exhibit rapid $\mathrm{H}_{2}$ release rates at only $100^{\circ} \mathrm{C}$. Currently there are no metastable metal hydrides that can meet these two extremes within such a narrow temperature window and there is considerable interest in engineering a hydride with a steep slope in Arrhenius plot (Figures 7 and 10) to meet this need.

A kinetically controlled tank must also have a rapid thermal response to keep up with the frequent stops and starts in many applications. This is especially difficult for larger systems, such as a $100 \mathrm{~kg}$ hydride bed for automotive applications, where the rapid heating and cooling of a large thermal mass is impractical. In this case, it would likely be better to decompose only a small portion of the material at a time by segmenting the tank or using a cartridgetype system. Another option is to use a pumpable powder or slurry, where the fuel could be pumped into a reactor and thermally decomposed. In this design, the reactor temperature is kept constant and the rate of $\mathrm{H}_{2}$ release is controlled by the rate of the slurry supplied to the reactor. In addition to the rapid thermal response of a small reactor, this method would also allow the tank to be partitioned. A separate volume for the unreacted fuel (e.g., $\left.\mathrm{AlH}_{3}\right)$ and the spent fuel (e.g., Al metal) is essential for off-board refueling. With this type of tank configuration only the used portion of the fuel is replaced during off-board refueling.

\section{Regeneration}

Despite their high capacity and rapid low temperature kinetics, the metastable metal hydrides are currently not practical storage media for most applications since they cannot be 
rehydrogenated at reasonable pressures and temperatures. The primary barrier to using metastable metal hydrides as a hydrogen source for mobile fuel cell applications is the cost associated with making the material. Although these materials are easily synthesized through a variety of chemical routes (see reactions (2)-(8)), the cost of the precursors is generally unacceptably high for large-scale commercial applications. For this reason (along with environmental reasons), there is much interest in identifying a closedloop regeneration procedure where all of the materials (except for the hydrogen) are reused to reform the hydride. Unfortunately, the byproducts formed during the chemical synthesis of most metastable hydrides are stable compounds (e.g., $\mathrm{LiCl}$ ) that are energetically costly to separate or recycle. A recent study on $\mathrm{AlH}_{3}$ revealed that even under optimal conditions, a perfectly efficient recycling reaction for $\mathrm{AlH}_{3}$ would still require an energy input of $167 \mathrm{~kJ} / \mathrm{mol} \mathrm{H}_{2}$, which is equivalent to approximately $70 \%$ of the fuel energy contained within $\mathrm{AlH}_{3}$ [92]. In a more realistic, industrialscale process this method would likely require a much greater energy input, many time greater than the energy contained within the material.

Given the high cost associated with the direct chemical synthesis, it is reasonable to consider alternative routes of reforming the hydride from the spent (hydrogen depleted) material. Due to their low stability, the metastable metal hydrides are not easily rehydrogenated under moderate pressure and temperature conditions. In recent years there has been considerable effort focused on identifying low energy regeneration pathways to prepare the hydride from the dehydrogenated material (e.g., spent fuel). Baranowski succeeded in forming $\mathrm{AlH}_{3}$ by direct hydrogenation of $\mathrm{Al}$ metal at high pressures $\left(3 \times 10^{4}\right.$ bar at $\left.573 \mathrm{~K}\right)$ [88]. A number of other high pressure [87, 89-91] and thermodynamic studies [20, 44, 45] on the Al-H system have also been performed, which have recently been compiled into a pressure-temperature phase diagram, shown in Figure 11 [28]. The problem is clearly evident in this plot - the direct hydrogenation of aluminum requires pressures $>7 \mathrm{kbar}$ (almost 7000 atmospheres) at room temperature, much too high to be practical for largescale commercial applications. Other metastable hydrides have proven to be even more difficult to rehydrogenate and most of them (e.g., $\mathrm{LiAlH}_{4}, \mathrm{Mg}\left(\mathrm{AlH}_{4}\right)_{2}, \mathrm{Ca}\left(\mathrm{AlH}_{4}\right)_{2}$ ) have never been formed by direct hydrogenation at any pressure.

10.1. Electrochemical Regeneration. Given the high cost of the direct chemical synthesis and the high pressures required for direct hydrogenation, there are currently a number of efforts focused on regeneration of the metastable metal hydrides. In one method, the hydrogenation is performed electrochemically. In the most direct approach, an electrolytic potential is used to increase the hydrogen activity and drive the hydrogen into the host material. The electrolytic potential $(E)$ is related to the hydrogen pressure $\left(P_{\mathrm{H}_{2}}\right)$ through the Nernst equation:

$$
E=-\frac{R T}{2 F} \ln P_{\mathrm{H}_{2}},
$$

where $R$ is the universal gas constant, $T$ is the temperature, and $F$ is the Faraday constant. Since the potential scales as the

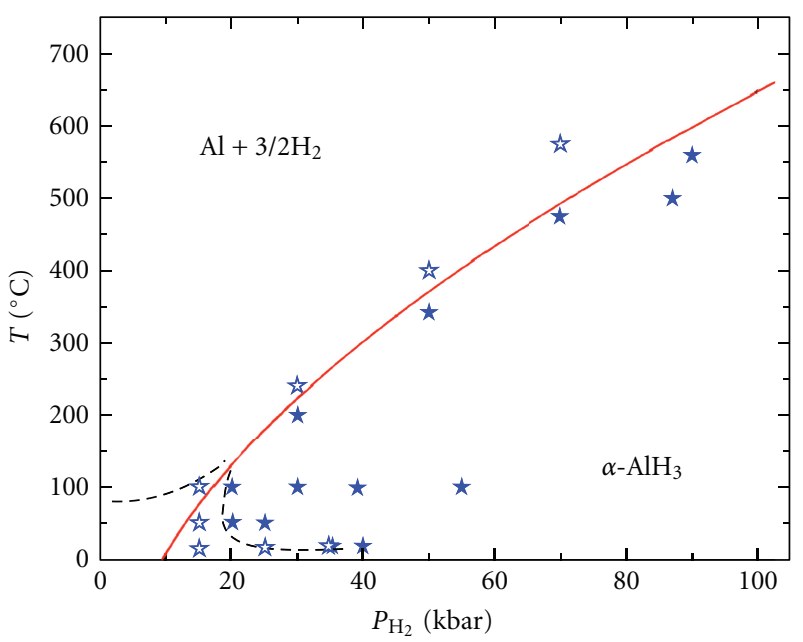

FIGURE 11: Pressure-temperature phase diagram of the Al-H system showing a solid line representing the calculated equilibrium for $\mathrm{AlH}_{3} \longleftrightarrow \mathrm{Al}+3 / 2 \mathrm{H}_{2}$. The markers represent experimental results over a variety of pressure and temperature conditions, with the solid stars indicating the formation of $\alpha-\mathrm{AlH}_{3}$ and the open stars indicating no reaction [28].

natural $\log$ of the pressure, this equation indicates that the thermodynamic barrier to hydrogenation can be overcome by a relatively low voltage. Investigations of electrochemical hydrogenation of aluminum date back to the early 1960s when Clasen used an aluminum anode and an iron/mercury cathode with an electrolyte of $\mathrm{NaAlH}_{4}$ in THF [110]. In the late 1990s, Birnbaum et al. used aqueous solutions of $\mathrm{H}_{2} \mathrm{SO}_{4}$ and $\mathrm{HCl}$ along with a recombination poison $\left(\mathrm{NaAsO}_{4}\right)$ to achieve high hydrogen fugacities for cathodic charging of aluminum [111]. They demonstrated that hydrogen enters vacancies in the $\mathrm{Al}$ structure and achieved concentrations of $>1000 \mathrm{ppm}$, but no transformation to $\alpha-\mathrm{AlH}_{3}$ was observed. More recently, Zidan et al. $[112,113]$ have investigated the possibility of electrochemically charging $\mathrm{Al}$ with $\mathrm{H}$ using a cell similar to that of Clasen. In this case the electrochemical cell consisted of a pure $\mathrm{Al}$ anode and a platinum (foil or wire) cathode using THF with dissolved $\mathrm{NaAlH}_{4}$ as the electrolyte. In this reaction three $\mathrm{AlH}_{4}^{-}$ions (from $\mathrm{NaAlH}_{4}$ ) combine with one $\mathrm{Al}^{3+}$ ion (from anode) to generate four moles of solvated $\mathrm{AlH}_{3}$ at the anode as shown for the (anode) reaction below:

$$
3 \mathrm{AlH}_{4}^{-}+\mathrm{Al}^{3+}+n \mathrm{THF} \longrightarrow 4 \mathrm{AlH}_{3} \cdot n \mathrm{THF}
$$

The $\mathrm{AlH}_{3}-n$ THF adduct is a white solid, and it is typically difficult to remove the $\mathrm{AlH}_{3}$ intact. The desolvation requires high temperatures to break the Al-O bond and once the THF is removed the hydride begins decomposing, leading to a final product consisting of a mixture of $\mathrm{Al}$ and $\mathrm{AlH}_{3}$. Improvements in yield and efficiency were achieved by the use of additives, such as the introduction of $\mathrm{LiAlH}_{4}$ to the THF, along with the addition of $\mathrm{LiCl}$, which acts as an electrocatalytic additive (ECA). The use of $\mathrm{LiCl}$ enhances the electrochemical process, leading to a higher cell efficiency and better overall yields [111]. Similar regeneration reactions 
can be envisioned for other metastable metal hydrides, such as $\mathrm{LiAlH}_{4}$ or $\mathrm{Mg}\left(\mathrm{AlH}_{4}\right)_{2}$.

In this particular procedure three-quarters of the $\mathrm{AlH}_{3}$ come from splitting the alanate $\left(\mathrm{NaAlH}_{4}\right)$ and one-quarter is due to $\mathrm{Al}$ hydrogenation (consumption of the anode). It is worth noting that reaction (14) is similar to the conventional chemical synthesis of $\mathrm{AlH}_{3}$ (reaction (2)) where the $\mathrm{Al}^{-}$ ions from $\mathrm{AlCl}_{3}$ are replaced by $\mathrm{Al}^{-}$ions from the anode. Removing the chloride from the reaction is an important step towards achieving a low energy regeneration process since it eliminates the need to break up the salt (e.g., $\mathrm{LiCl}$ ).

Although the above reaction is an improvement over the conventional synthesis, this procedure still requires a costly precursor, $\mathrm{NaAlH}_{4}$, which is consumed during the reaction. Importantly, however, the $\mathrm{NaAlH}_{4}$ can also be reformed along with the spent fuel and the byproducts of the electrochemical reaction using the well-known hydrogenation process of Bogdanović and Schwickardi [9]. After the alane is formed, sodium from the electrolyte is deposited on the platinum electrode, either in the form a metallic sodium or, if hydrogen gas is present, in the form of sodium hydride. In the latter case, the $\mathrm{NaH}$ (recovered from the cathode) can be reacted with the spent material (e.g., Al metal) and $\mathrm{H}_{2}$ gas to reform $\mathrm{NaAlH}_{4}$ [9]. This last step, the formation of $\mathrm{NaAlH}_{4}$ from $\mathrm{NaH}$ and $\mathrm{Al}$, requires a catalyst, typically a transition metal such as titanium. When all steps are combined, electrochemical synthesis of alane along with the reformation of $\mathrm{NaAlH}_{4}$ by direct hydrogenation, this procedure yields a complete, closed-loop regeneration pathway for $\mathrm{AlH}_{3}$ where the only thing added and consumed during the cycle is hydrogen gas.

10.2. Chemical Regeneration. Another promising approach to the regeneration of metastable metal hydrides involves a multistep, chemical process for hydride formation. In its simplest form, this is a two-step process involving hydride stabilization through the formation of a hydride adduct followed by separation and hydride recovery. Although the formation of metastable hydrides by direct hydrogenation typically requires extremely high pressures, this barrier can be substantially reduced by the addition of a stabilizing agent that forms an adduct with the hydride. Since these metastable hydride (e.g., $\mathrm{AlH}_{3}$ ) can be generally classified as Lewis acids, the appropriate stabilizing agents are Lewis bases, such as ethers or amines. For example, in the presence of an amine, aluminum powder can be readily hydrogenated at pressures of a few bar, considerably lower than the $30 \mathrm{kbar}$ required to hydrogenate aluminum (at $300^{\circ} \mathrm{C}$ ) in the absence of a stabilizing amine [114-118]. Once the hydride is formed, the second step involves the removal of the stabilizing ligand and the recovery of the pure $\mathrm{AlH}_{3}$. Generic examples of the regeneration procedure for $\mathrm{AlH}_{3}$ and $\mathrm{MAlH}_{4}$ are given below:

$$
\begin{gathered}
\mathrm{Al}+\mathrm{L}+\frac{3}{2} \mathrm{H}_{2} \longrightarrow \mathrm{AlH}_{3}-\mathrm{L} \longrightarrow \mathrm{AlH}_{3} \downarrow+\mathrm{L} \uparrow \\
\mathrm{MH}+\mathrm{Al}+\mathrm{L}+\frac{3}{2} \mathrm{H}_{2} \longrightarrow \mathrm{MAlH}_{4}-\mathrm{L} \longrightarrow \mathrm{MAlH}_{4} \downarrow+\mathrm{L} \uparrow
\end{gathered}
$$

This method can be used to regenerate a variety of metastable metal hydrides $\left(\mathrm{AlH}_{3}, \mathrm{LiAlH}_{4}, \mathrm{Mg}\left(\mathrm{AlH}_{4}\right)_{2}\right.$, and $\left.\mathrm{Ca}\left(\mathrm{AlH}_{4}\right)_{2}\right)$, which cannot be formed by direct hydrogenation. One of the best examples is $\mathrm{LiAlH}_{4}$, which cannot be reformed from $\mathrm{LiH}$ and $\mathrm{Al}$ powder directly, but in the presence of tetrahydrofuran will form the adduct $\mathrm{LiAlH}_{4}$ THF at $\mathrm{H}_{2}$ pressures of $\sim 350$ bar $[69,119,120]$. A more recent study demonstrated that the addition of a Ti catalyst lowered the hydrogenation pressure to just a few bar at room temperature [121]. Once the adduct is formed it can decomposed at low temperature $\left(60-70^{\circ} \mathrm{C}\right)$ under partial vacuum to remove the THF and recover the $\mathrm{AlH}_{3}$ [119]. The full regeneration procedure for $\mathrm{LiAlH}_{4}$ is given below:

$$
\begin{aligned}
\mathrm{LiH}+\mathrm{Al}^{*}+n \mathrm{THF}+\frac{3}{2} \mathrm{H}_{2} & \longrightarrow \mathrm{LiAlH}_{4}-n \mathrm{THF} \\
& \longrightarrow \mathrm{LiAlH}_{4} \downarrow+n \mathrm{THF} \uparrow
\end{aligned}
$$

where $\mathrm{Al}^{*}$ represents titanium-catalyzed aluminum. The hydrogenation reaction (first step in reaction (16)) is reversible and the thermodynamics were investigated by measuring pressure-composition isotherms. The free energy was found to be small and slightly negative $\left(\Delta \mathrm{G}=-1.1 \mathrm{~kJ} / \mathrm{mol} \mathrm{H}_{2}\right)$, suggesting an equilibrium hydrogen pressure of just under $1 \mathrm{bar}$ at room temperature [119]. More recently, a similar approach was adopted using dimethyl ether $\left(\mathrm{DME}=\mathrm{Me}_{2} \mathrm{O}\right)$, rather than THF, as the stabilizing ligand, as shown below [122]:

$$
\begin{aligned}
\mathrm{LiH}+\mathrm{Al}^{*}+n \mathrm{Me}_{2} \mathrm{O}+\frac{3}{2} \mathrm{H}_{2} & \longrightarrow \mathrm{LiAlH}_{4}-n \mathrm{Me}_{2} \mathrm{O} \\
& \longrightarrow \mathrm{LiAlH}_{4} \downarrow+n \mathrm{Me}_{2} \mathrm{O} \uparrow
\end{aligned}
$$

In this process the use of DME over THF may be more convenient since the DME is a gas at room temperature and it is easily removed after hydrogenation by simply venting the reactor. In the full regeneration procedure the dehydrogenated product $\left(\mathrm{LiH}+\mathrm{Al}^{*}\right)$ is dissolved in $\mathrm{Me}_{2} \mathrm{O}$ at a hydrogen pressure of 100 bar. After 24 hours at room temperature, the gases $\mathrm{H}_{2}$ and $\mathrm{Me}_{2} \mathrm{O}$ are released and the remaining solid material in the reactor is catalyzed $\mathrm{LiAlH}_{4}$. Cycling studies of $\mathrm{LiAlH}_{4}$ (Ti catalyzed) produced by this method (reaction (17)) showed a hydrogen release of $7 \mathrm{wt} . \%$ $\left(80-180^{\circ} \mathrm{C}\right)$ over 5 regeneration cycles [123].

A similar type of regeneration procedure (consisting of a stabilization step followed by separation) is also being pursued for aluminum hydride. Early studies of Ashby demonstrated hydrogenation of $\mathrm{Al}$ powder at moderate pressures in the presence of triethylenediamine (TEDA) [112]. More recently, the hydrogenation pressure required for this reaction was further reduced by the use of a transition metal catalysts (e.g., Ti). The hydrogenation of catalyzed $\mathrm{Al}^{*}$ and an amine $\left(\mathrm{NR}_{3}\right)$, to form an alane amine adduct, is shown below:

$$
\mathrm{Al}^{*}+x \mathrm{NR}_{3}+\frac{3}{2} \mathrm{H}_{2} \longleftrightarrow \mathrm{AlH}_{3}-x \mathrm{NR}_{3}
$$




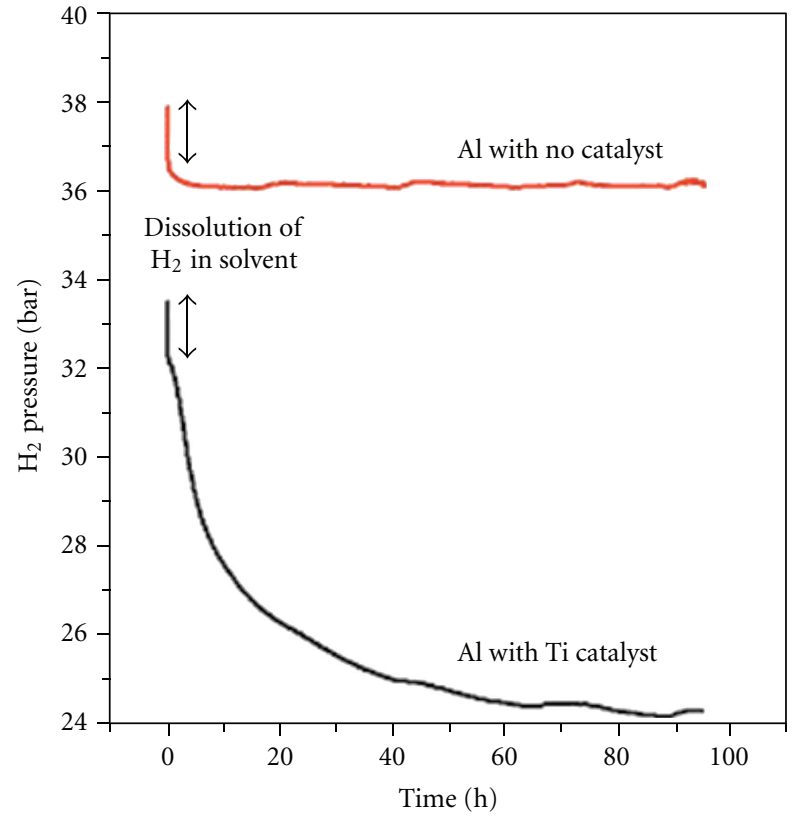

Figure 12: Uptake of hydrogen in a TEDA/THF solution with Al powder in suspension showing the pressure change for Ticatalyzed (lower trace) and uncatalyzed (upper trace) slurries at room temperature. The rapid drop in pressure within the first few minutes is due to the dissolution of $\mathrm{H}_{2}$ in the solvent [113].

In this reversible reaction, the catalyzed $\mathrm{Al}$ powder $\left(\mathrm{Al}^{*}\right)$ is stirred into a solution with the amine and a solvent (e.g., tetrahydrofuran). The application of moderate hydrogen pressures $(1-100$ bar $)$ at low temperature $\left(23-80^{\circ} \mathrm{C}\right)$ results in the formation of $x \mathrm{NR}_{3}-\mathrm{AlH}_{3}$, where $x$ is typically 1 or 2. Figure 12 shows the drop in hydrogen pressure associated with the hydrogenation of $\mathrm{Al}$ and triethylenediamine (TEDA) in THF to form TEDA- $\mathrm{AlH}_{3}$ at room temperature. In this particular case, the TEDA (solid) was dissolved in THF and added to the catalyzed $\mathrm{Al}^{*}$ powder in the reactor. There is initially no reaction with the application of hydrogen ( $\sim 35$ bar $)$ until the solution is agitated (stirrer activated), at which point there is an immediate pressure drop due to dissolution of $\mathrm{H}_{2}$ into the solution. In the case of the Ti-catalyzed $\mathrm{Al}$, the hydrogenation reaction proceeds slowly and is complete after $\sim 3$ days. The product, TEDA-AlH 3 is insoluble in THF (and most solvents) and precipitates out of solution as a white solid. It is interesting to note that the same experiment performed with uncatalyzed $\mathrm{Al}$ powder does not react, clearly indicating that a small amount of a transition metal catalyst $(<2 \mathrm{~mol} \%)$ is necessary to perform these hydrogenation reactions at low pressures [113].

More recent studies focused on alane adduct formation by direct hydrogenation have demonstrated that a number of other tertiary amines are also effective at stabilizing $\mathrm{AlH}_{3}$ including trimethylamine (TMA), quinuclidine, hexamine, and dimethylethylamine (DMEA). These compounds typically form $1: 1$ or $2: 1$ adducts $\left(\mathrm{NR}_{3}: \mathrm{AlH}_{3}\right)$ depending upon the concentration. The molecular structures for a few different amine alane adducts are shown in Figure 13 (type of

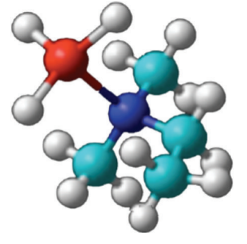

(a)

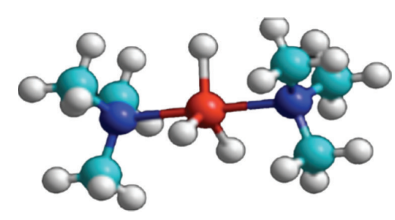

(c)

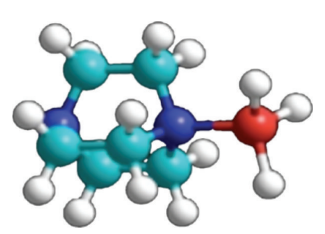

(b)

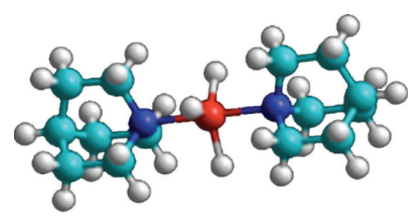

(d)
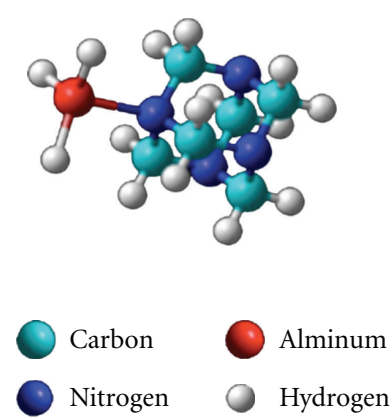

(e)

FIGURE 13: Adducts of $\mathrm{AlH}_{3}$ formed by direct hydrogenation showing (a) dimethylethylamine (DMEA) alane, (b) triethylenediamine (TEDA) alane, (c) trimethylamine (TMA) alane, (d) quinuclidine alane, and (e) hexamine alane. It is important to note that amine alane adducts can form different complexes (e.g., mono, bis, and dimer) depending upon conditions (e.g., concentration). The structures shown are not necessarily the most stable configurations.

adduct shown (e.g., $2: 1$ or $1: 1$ ) is not necessarily the most stable).

The formation of alane adducts by direct hydrogenation of $\mathrm{Al}$ is a relatively simple reaction that works under mild condition with a variety of amines. However, in order to recover $\mathrm{AlH}_{3}$ from the adduct, the stabilizing molecule (amine) must be removed without decomposing the hydride. This has proven to be the primary obstacle for alane regeneration since all of the amine alane adducts shown in Figure 13 are very stable. Unlike alane etherates, which have a relatively weak $\mathrm{Al}-\mathrm{O}$ bond and can be separated at low temperature $\left(60-70^{\circ} \mathrm{C}\right)$, the $\mathrm{Al}$ in the alane amines is more tightly bound to the $\mathrm{N}$, making the direct separation of $\mathrm{NR}_{3}-\mathrm{AlH}_{3}$ more difficult. Typically, the separation, or desolvation, of most alane amines occurs at temperatures well above $100^{\circ} \mathrm{C}$ where the $\mathrm{AlH}_{3}$ is unstable. Once the amine is removed, the alane rapidly releases $\mathrm{H}_{2}$ and decomposes to $\mathrm{Al}$ metal.

The challenges associated with separating alane amines have led to a search for less stable adducts and to date, there is only one known amine that can be separated from $\mathrm{AlH}_{3}$ at low temperature $\left(70^{\circ} \mathrm{C}\right)$, triethylamine (TEA). However, despite numerous attempts, TEA-AH $\mathrm{AH}_{3}$ is not easily formed 
by direct hydrogenation (reaction (18)). In this case, the Al$\mathrm{N}$ bond is weaker than most other alane amines and the large ethyl groups may also sterically hinder adduct formation. Currently, the search is underway for the "Goldilocks" compound, which forms a bond strong enough to stabilize the hydride, but weak enough so that the adduct can be separated at low temperature.

One way of circumventing this issue may be to simply use two different amines for the regeneration, one that forms a strong $\mathrm{Al}-\mathrm{N}$ bond for the hydrogenation, and a second that forms a weak Al-N bond for the separation. In this case an amine exchange reaction, also known as transamination, is necessary to transform one adduct into the other. Although the transamination is energetically uphill, this type of reaction can be driven by exploiting the law of mass action. In this case, a solution is prepared where the second amine (which forms the less stable adduct) is maintained at a high concentration and the first amine (which forms the more stable adduct) is preferentially removed. This type of reaction places restrictions on the choice of amines, since the first amine must form a more stable adduct and should have a higher vapor pressure than the second amine or the adduct. It was recently demonstrated that the amines in DMEA-AlH and TMA- $\mathrm{AlH}_{3}$ could be exchanged with TEA to form TEA$\mathrm{AlH}_{3}$ under mild conditions, as shown below $[114,116]$ :

$$
\mathrm{NR}_{3}-\mathrm{AlH}_{3}+\mathrm{TEA} \longrightarrow \mathrm{TEA}-\mathrm{AlH}_{3}+\mathrm{NR}_{3} \uparrow
$$

The progress of the transamination reaction can be followed using Fourier transform infrared (FTIR) spectroscopy since the positions of the $\mathrm{Al}-\mathrm{H}$ stretch peaks for TMA-AlH (Al-H peak at $1710 \mathrm{~cm}^{-1}$ ) and TEA-AlH 3 (Al-H stretch at $1777 \mathrm{~cm}^{-1}$ ) are separated by $67 \mathrm{~cm}^{-1}$. Figure 14 shows the FTIR spectra from the initial hydrogenation product (TMA$\mathrm{AlH}_{3}$ ) on the bottom and a spectrum from a standard sample of TEA-AlH ${ }_{3}$ on the top. Triethylamine was added to the TMA-AlH ${ }_{3}$ in diethyl ether and stirred for several hours at $55^{\circ} \mathrm{C}$ under a sweep of nitrogen gas. The formation of triethylamine alane is indicated by the growth of a new peak at $1777 \mathrm{~cm}^{-1}$ (middle spectrum), which is complete after approximately 3 hrs.

The final step in the regeneration process involves the separation of TEA-AlH $\mathrm{An}_{3}$ into TEA and $\mathrm{AlH}_{3}$. Although this can be accomplished a few different ways, the most common method involves heating the $\mathrm{TEA}-\mathrm{AlH}_{3}$ to $75^{\circ} \mathrm{C}$ under a nitrogen sweep or partial vacuum for $\sim 4$ hours, as shown below:

$$
\mathrm{AlH}_{3}-\mathrm{TEA} \longrightarrow \mathrm{AlH}_{3} \downarrow+\mathrm{TEA} \uparrow
$$

The TEA is removed as a gas (recovered in a trap) and the remaining solid is crystalline $\alpha-\mathrm{AlH}_{3}$. X-ray diffraction patterns of the material recovered from TEA-AlH $\mathrm{H}_{3}$ showed primarily $\alpha-\mathrm{AlH}_{3}(\sim 90 \mathrm{~mol} \%)$, with a small amount of $\mathrm{Al}$ $(\sim 10 \mathrm{~mol} \%)$.

The complete low energy regeneration procedure for $\alpha$ $\mathrm{AlH}_{3}$ is summarized in Figure 15. In this particular example DMEA is used to stabilize the alane during hydrogenation in step 1 (TMA could also be used for this step). Step 2 involves exchanging TEA for DMEA (transamination) to

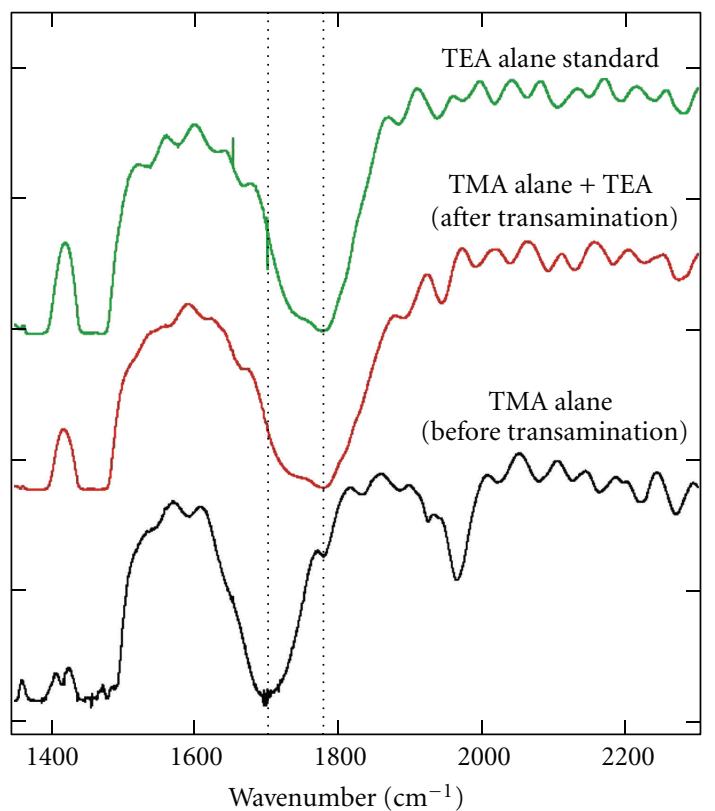

FIgURE 14: FTIR spectra from the TEA-AlH 3 standard (top), TMA$\mathrm{AlH}_{3}$ (bottom), and the reaction product after transamination, identified as TEA- $\mathrm{AlH}_{3}$ (middle) [116].

form TEA-AlH 3 , which is separated in step 3 to recover $\mathrm{AlH}_{3}$. Although each of the steps necessary to regenerate $\mathrm{AlH}_{3}$ (reactions (18)-(20)) has been independently verified, the integration of all three steps remains a significant challenge. More work is needed to improve the product yields at each stage of the procedure and incorporate and simplify the three steps (hydrogenation, transamination, and separation) into a single process.

One of the primary concerns with the regeneration of metastable metal hydrides is the energy required to execute this process. In 2011 an independent analysis of $\mathrm{AlH}_{3}$ regeneration described above (using TMA) was conducted by Hua and Ahluwalia assuming $100 \%$ conversion during hydrogenation, $75 \%$ yields in the transamination step, and $75 \%$ in the $\mathrm{TEA}-\mathrm{AlH}_{3}$ separation step [124]. They found that the production of $10 \mathrm{~kg}$ of $\mathrm{AlH}_{3}\left(1 \mathrm{~kg}\right.$ of $\left.\mathrm{H}_{2}\right)$ required $\sim 511 \mathrm{MJ}$ of energy (natural gas and electricity). This energy consumption includes regeneration energy $(\sim 341 \mathrm{MJ})$ and the energy it takes to make the $1 \mathrm{~kg}$ of hydrogen in the first place from natural gas $(\sim 170 \mathrm{MJ})$. Given that $10 \mathrm{~kg}$ of $\mathrm{AlH}_{3}$ contains $121 \mathrm{MJ}$ of energy (based on the lower heating value of $\mathrm{H}_{2}$ ), the well-to-tank (WTT) efficiency is $\sim 24 \%$. Since the temperatures for all regeneration steps in Figure 15 are typically low $\left(<80^{\circ} \mathrm{C}\right)$, improvements in efficiency can be achieved by using industrial waste heat rather than natural gas for the heating requirements. In this case the WTT efficiencies were estimated to be $37 \%$ [122]. More recently, the WTT efficiencies for $\mathrm{AlH}_{3}$ regeneration were raised to $41-54 \%$, based upon improvements in the regeneration procedure [125]. Although these values still fall short of the US Department of Energy target of $60 \%$, the efficiency of 

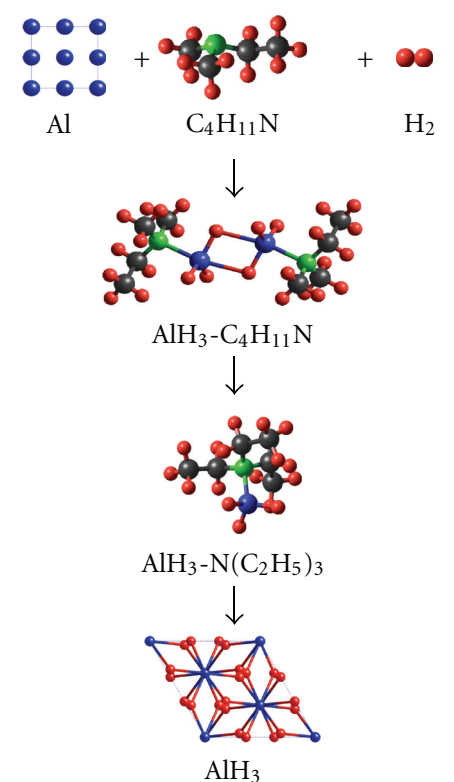

FIgURE 15: Regeneration pathway for $\mathrm{AlH}_{3}$ showing hydrogenation of $\mathrm{Al}$ and dimethylethylamine $\left(\mathrm{C}_{4} \mathrm{H}_{11} \mathrm{~N}\right)$ to form DMEA-AlH $\mathrm{D}_{3}$ (step 1), followed by transamination to form $\mathrm{TEA}^{-\mathrm{AlH}_{3}}$ (step 2), and separation to recover $\mathrm{AlH}_{3}$ (step 3) [114].

alane regeneration is estimated to be greater than other offboard hydrides, such as ammonia borane, which is estimated to have WTT efficiencies of $12-37 \%$.

\section{Where Do We Go from Here?}

There is currently a growing need for innovative energy storage systems to supply power at all scales, from small microelectronics to the electrical grid. Although metastable metal hydrides are clearly unsuitable for many of these applications, they exhibit a few important properties that could prove especially useful for mobile applications: (i) low pressure hydrogen storage, (ii) high volumetric and gravimetric hydrogen density, and (iii) low temperature hydrogen release. Recently, two metastable metal hydrides, $\mathrm{AlH}_{3}$ and $\mathrm{LiAlH}_{4}$, were identified as two of only a few "near term materials" for vehicular hydrogen storage [126]. Despite many of the advantages of using a metastable hydride for automotive applications, two key challenges need to be overcome. The first is regeneration; although a few different pathways have been identified, the cost will need to come down (WTT efficiencies need to increase to $60 \%$ or more). The second challenge is the system engineering; current designs are focused on using hydride slurries to move the material into an external reactor, but that introduces a number of new challenges such as keeping the slurry flowing before and after decomposition.

In the near term, the metastable metal hydrides are ideally suited for a variety of other applications. These compounds (e.g., $\mathrm{AlH}_{3}, \mathrm{LiAlH}_{4}$ ), along with their amine adducts, are valuable chemical reductants that can be used (and is some cases are currently being used) to synthesize a variety of chemical compounds. For hydrogen storage applications, these materials are well suited to high value portable electronics that require lightweight and compact energy storage systems. Increasing demand for power systems built into backpacks, jackets, and clothing for military, industrial, and recreational use has generated much interest in $\mathrm{AlH}_{3}$ in recent years. In addition, these materials may also be ideally suited to unmanned aerial vehicles (UAV). It is also worth noting that these hydrides can be tailored to release hydrogen on demand, either through low temperature thermolysis, hydrolysis, or both. When reacted with water (hydrolysis), hydrogen is released from the hydride and from the water increasing the total $\mathrm{H}_{2}$ yield. This type of system may be especially useful for marine application (e.g., unmanned submersibles) where the water is available and does not need to be carried onboard. In many of these applications the amount of hydride used is relatively small so the cost is expected to be low relative to the cost of the device (e.g., $\mathrm{UAV})$. In these cases the hydride would likely be prepared through the conventional synthesis procedure (rather than regenerated), which would allow the spent fuel to be discarded after use.

\section{Summary}

The kinetically stabilized metal hydrides offer a new approach to hydrogen storage. The low heat of decomposition and rapid low temperature kinetics make these hydrides promising candidates for high value portable electronics in the near term and possibly automotive applications in the long term. For larger-scale applications a number of key challenges need to be overcome. These materials are not reversible at practical $\mathrm{H}_{2}$ pressures and the conventional organometallic synthesis routes are costly. The utility of these materials will require new cost-effective and energetically efficient methods to regenerate or recycle the hydride from the spent fuel and reaction products. In addition, new hydrogen storage systems will need to be designed, specifically for the metastable metal hydrides, that enable a controllable hydrogen release within a narrow temperature window.

\section{Acknowledgments}

This paper has been authored by Brookhaven Science Associates, LLC under Contract no. DE-AC02-98CH1-886 with the US Department of Energy.

\section{References}

[1] "Basic research needs for electrical energy storage," Report of the Basic Energy Sciences Workshop on Electrical Energy Storage, US Department of Energy, 2007.

[2] M. Hirscher and B. Panella, "Hydrogen storage in metalorganic frameworks," Scripta Materialia, vol. 56, no. 10, pp. 809-812, 2007.

[3] A. G. Wong-Foy, A. J. Matzger, and O. M. Yaghi, "Exceptional $\mathrm{H}_{2}$ saturation uptake in microporous metal-organic frameworks," Journal of the American Chemical Society, vol. 128, no. 11, pp. 3494-3495, 2006. 
[4] A. Dailly, J. J. Vajo, and C. C. Ahn, "Saturation of hydrogen sorption in $\mathrm{Zn}$ benzenedicarboxylate and $\mathrm{Zn}$ naphthalenedicarboxylate," Journal of Physical Chemistry B, vol. 110, no. 3, pp. 1099-1101, 2006.

[5] B. Panella, M. Hirscher, H. Pütter, and U. Müller, "Hydrogen adsorption in metal-organic frameworks: $\mathrm{Cu}-\mathrm{MOF}$ and $\mathrm{Zn}$ MOFs compared," Advanced Functional Materials, vol. 16, no. 4, pp. 520-524, 2006.

[6] R. Chahine and T. K. Bose, "Low-pressure adsorption storage of hydrogen," International Journal of Hydrogen Energy, vol. 19, no. 2, pp. 161-164, 1994.

[7] B. Panella, M. Hirscher, and S. Roth, "Hydrogen adsorption in different carbon nanostructures," Carbon, vol. 43, no. 10, pp. 2209-2214, 2005.

[8] X. Lin, J. Jia, X. Zhao et al., "High $\mathrm{H}_{2}$ adsorption by coordination-framework materials," Angewandte Chemie, vol. 45, no. 44, pp. 7358-7364, 2006.

[9] B. Bogdanović and M. Schwickardi, "Ti-doped alkali metal aluminium hydrides as potential novel reversible hydrogen storage materials," Journal of Alloys and Compounds, vol. 253254, pp. 1-9, 1997.

[10] J. Graetz, Y. Lee, J. J. Reilly, S. Park, and T. Vogt, "Structures and thermodynamics of the mixed alkali alanates," Physical Review B, vol. 71, no. 18, Article ID 184115, 2005.

[11] L. M. Arnbjerg and T. R. Jensen, "New compounds in the potassium-aluminium-hydrogen system observed during release and uptake of hydrogen," International Journal of Hydrogen Energy, vol. 37, no. 1, pp. 345-356, 2012.

[12] G. Sandrock, J. Reilly, J. Graetz, W. M. Zhou, J. Johnson, and J. Wegrzyn, "Accelerated thermal decomposition of $\mathrm{AlH}_{3}$ for hydrogen-fueled vehicles," Applied Physics A, vol. 80, no. 4, pp. 687-690, 2005.

[13] E. Fakioğlu, Y. Yürüm, and T. N. Veziroğlu, "A review of hydrogen storage systems based on boron and its compounds," International Journal of Hydrogen Energy, vol. 29, no. 13, pp. 1371-1376, 2004.

[14] F. H. Stephens, V. Pons, and R. T. Baker, "Ammonia-borane: the hydrogen source par excellence?" Dalton Transactions, no. 25, pp. 2613-2626, 2007.

[15] A. Staubitz, A. P. M. Robertson, and I. Manners, "AmmoniaBorane and related compounds as dihydrogen sources," Chemical Reviews, vol. 110, no. 7, pp. 4079-4124, 2010.

[16] N. C. Smythe and J. C. Gordon, "Ammonia borane as a hydrogen carrier: dehydrogenation and regeneration," European Journal of Inorganic Chemistry, no. 4, pp. 509-521, 2010.

[17] T. Hua, R. Ahluwalia, J. -K Peng et al., "Technical assessment of compressed hydrogen storage tank systems for automotive applications," U.S. Department of Energy Report prepare by Argonne National Laboratory, 2010, http://wwwl.eere.energy.gov/hydrogenandfuelcells/pdfs/compressedtank_storage .pdf/.

[18] J. W. Turley and H. W. Rinn, "The crystal structure of aluminum hydride," Inorganic Chemistry, vol. 8, no. 1, pp. $18-22,1969$.

[19] J. Graetz and J. J. Reilly, "Decomposition kinetics of the $\mathrm{AlH}_{3}$ polymorphs," Journal of Physical Chemistry B, vol. 109, no. 47, pp. 22181-22185, 2005.

[20] J. Graetz and J. J. Reilly, "Thermodynamics of the $\alpha, \beta$ and $\gamma$ polymorphs of $\mathrm{AlH}_{3}$," Journal of Alloys and Compounds, vol. 424, no. 1-2, pp. 262-265, 2006.

[21] H. W. Brinks, A. Istad-Lem, and B. C. Hauback, "Mechanochemical synthesis and crystal structure of $\alpha^{\prime}-\mathrm{AlD}_{3}$ and $\alpha$ $\mathrm{AlD}_{3}$," Journal of Physical Chemistry B, vol. 110, no. 51, pp. 25833-25837, 2006.
[22] H. W. Brinks, W. Langley, C. M. Jensen, J. Graetz, J. J. Reilly, and B. C. Hauback, "Synthesis and crystal structure of $\beta$ $\mathrm{AlD}_{3}$," Journal of Alloys and Compounds, vol. 433, no. 1-2, pp. 180-183, 2007.

[23] V. A. Yartys, R. V. Denys, J. P. Maehlen et al., "Double-bridge bonding of aluminium and hydrogen in the crystal structure of $\gamma$ - $\mathrm{AlH}_{3}$," Inorganic Chemistry, vol. 46, no. 4, pp. 1051$1055,2007$.

[24] H. W. Brinks, C. Brown, C. M. Jensen, J. Graetz, J. J. Reilly, and B. C. Hauback, "The crystal structure of $\gamma-\mathrm{AlD}_{3}$," Journal of Alloys and Compounds, vol. 441, no. 1-2, pp. 364-367, 2007.

[25] J. Graetz, J. J. Reilly, J. G. Kulleck, and R. C. Bowman, "Kinetics and thermodynamics of the aluminum hydride polymorphs," Journal of Alloys and Compounds, vol. 446-447, pp. 271-275, 2007.

[26] S.-J. Hwang, R. C. Bowman, J. Graetz, J. J. Reilly, W. Langley, and C. M. Jensen, "NMR studies of the aluminum hydride phases and their stabilities," Journal of Alloys and Compounds, vol. 446, pp. 290-295, 2007.

[27] M. Tkacz, T. Palasyuk, J. Graetz, and S. Saxena, "Highpressure Raman spectroscopy study of $\alpha$ and $\gamma$ polymorphs of $\mathrm{AlH}_{3}$," Journal of Raman Spectroscopy, vol. 39, no. 7, pp. 922-927, 2008.

[28] J. Graetz, J. J. Reilly, V. A. Yartys et al., "Aluminum hydride as a hydrogen and energy storage material: past, present and future," Journal of Alloys and Compounds, vol. 509, no. 2, supplement, pp. S517-S528, 2011.

[29] D. Blanchard, H. W. Brinks, B. C. Hauback, P. Norby, and J. Muller, "Isothermal decomposition of LiAlD4 with and without additives," Journal of Alloys and Compounds, vol. 404-406, pp. 743-747, 2005.

[30] A. Andreasen, T. Vegge, and A. S. Pedersen, "Dehydrogenation kinetics of as-received and ball-milled LiAlH4," Journal of Solid State Chemistry, vol. 178, no. 12, pp. 3672-3678, 2005.

[31] A. Andreasen, "Effect of Ti-doping on the dehydrogenation kinetic parameters of lithium aluminum hydride," Journal of Alloys and Compounds, vol. 419, no. 1-2, pp. 40-44, 2006.

[32] K. M. Mackay, Hydrogen Compounds of the Metallic Elements, Spon, London, UK, 1966.

[33] T. N. Dymova, D. P. Aleksandrov, V. N. Konoplev, T. A. Silina, and A. S. Sizareva, "Spontaneous and thermaldecomposition of lithium tetrahydroaluminate $\mathrm{LiAlH}_{4}$ - the promoting effect of mechanochemical action on the process," Koordinatsionnaya Khimiya, vol. 20, no. 4, pp. 279-285, 1994.

[34] T. N. Dymova, D. P. Aleksandrov, V. N. Konoplev, and T. A. Silina, "Novel view of the nature of the chemical-composition and phase-composition modifications in lithium hydridoaluminates $\mathrm{LiAlH}_{4}$ and $\mathrm{LiAlH}_{6}$ on heating," Koordinatsionnaya Khimiya, vol. 21, no. 3, pp. 175-182, 1995.

[35] M. Fichtner and O. Fuhr, "Synthesis and structures of magnesium alanate and two solvent adducts," Journal of Alloys and Compounds, vol. 345, no. 1-2, pp. 286-296, 2002.

[36] O. M. Løvvik, S. M. Opalka, H. W. Brinks, and B. C. Hauback, "Crystal structure and thermodynamic stability of the lithium alanates $\mathrm{LiAlH}_{4}$ and $\mathrm{Li}_{3} \mathrm{AlH}_{6}$," Physical Review B, vol. 69, no. 13, Article ID 134117, 9 pages, 2004.

[37] M. Fichtner, O. Fuhr, and O. Kircher, "Magnesium alanatea material for reversible hydrogen storage?" Journal of Alloys and Compounds, vol. 356, pp. 418-422, 2003.

[38] M. Mamatha, B. Bogdanović, M. Felderhoff et al., "Mechanochemical preparation and investigation of properties of magnesium, calcium and lithium-magnesium alanates," 
Journal of Alloys and Compounds, vol. 407, no. 1-2, pp. 7886, 2006.

[39] E. Wiberg and R. U. Lacal, Zeitschrift für Naturforschung, vol. 6, p. 392, 1951.

[40] D. M. Liu, Z. X. Qian, T. Z. Si, and Q. A. Zhang, "Synthesis, crystal structure and thermal decomposition of $\mathrm{LiCa}\left(\mathrm{AlH}_{4}\right)_{3}$," Journal of Alloys and Compounds, vol. 520, pp. 202-206, 2012.

[41] S. I. Orimo, Y. Nakamori, J. R. Eliseo, A. Züttel, and C. M. Jensen, "Complex hydrides for hydrogen storage," Chemical Reviews, vol. 107, no. 10, pp. 4111-4132, 2007.

[42] M. Mamatha, C. Weidenthaler, A. Pommerin, M. Felderhoff, and F. Schüth, "Comparative studies of the decomposition of alanates followed by in situ XRD and DSC methods," Journal of Alloys and Compounds, vol. 416, no. 1-2, pp. 303-314, 2006.

[43] R. A. Varin and R. Parviz, "The effects of the micrometric and nanometric iron $(\mathrm{Fe})$ additives on the mechanical and thermal dehydrogenation of lithium alanate $\left(\mathrm{LiAlH}_{4}\right)$, its self-discharge at low temperatures and rehydrogenation," International Journal of Hydrogen Energy, vol. 37, pp. 90889102, 2012.

[44] M. J. Van Setten, G. A. De Wijs, V. A. Popa, and G. Brocks, "Ab initio study of $\mathrm{Mg}\left(\mathrm{AlH}_{4}\right)_{4}$," Physical Review B, vol. 72, no. 7, Article ID 073107, 2005.

[45] G. C. Sinke, L. C. Walker, F. L. Oetting, and D. R. Stull, "Thermodynamic properties of aluminum hydride," The Journal of Chemical Physics, vol. 47, no. 8, pp. 2759-2761, 1967.

[46] L. Schlapbach, "Hydrogen as a fuel and its storage for mobility and transport," MRS Bulletin, vol. 27, no. 9, pp. 675676, 2002.

[47] R. S. Irani, "Hydrogen storage: high-pressure gas containment," MRS Bulletin, vol. 27, no. 9, pp. 680-682, 2002.

[48] J. Wolf, "Liquid-hydrogen technology for vehicles," MRS Bulletin, vol. 27, no. 9, pp. 684-687, 2002.

[49] R. C. Bowman Jr. and B. Fultz, "Metallic hydrides I: hydrogen storage and other gas-phase applications," MRS Bulletin, vol. 27, no. 9, pp. 688-693, 2002.

[50] J. M. Joubert, M. Latroche, and A. Percheron-Guégan, "Metallic hydrides II: materials for electrochemical storage," MRS Bulletin, vol. 27, no. 9, pp. 694-698, 2002.

[51] E. Akiba and M. Okada, "Metallic hydrides III: bodycentered-cubic solid-solution alloys," MRS Bulletin, vol. 27, no. 9, pp. 699-703, 2002.

[52] A. Züttel and S. I. Orimo, "Hydrogen in nanostructured, carbon-related, and metallic materials," MRS Bulletin, vol. 27, no. 9, pp. 705-711, 2002.

[53] B. Bogdanović and G. Sandrock, "Catalyzed complex metal hydrides," MRS Bulletin, vol. 27, no. 9, pp. 712-716, 2002.

[54] O. Stecher and E. Wiberg, "A non-volatile, polymer aluminium hydrogen $\left(\mathrm{AlH}_{3}\right)_{x}$ and several volatile compounds of monomeric $\mathrm{AlH}_{3}$," Berichte der Deutschen Chemischen Gesellschaft, vol. 75, pp. 2003-2012, 1942.

[55] A. E. Finholt, A. C. Bond, and H. I. Schlesinger, "Lithium aluminum hydride, aluminum hydride and lithium gallium hydride, and some of their applications in organic and inorganic chemistry," Journal of the American Chemical Society, vol. 69, no. 5, pp. 1199-1203, 1947.

[56] G. Chizinsky, G. G. Evans, T. R. P. Gibb, and M. J. Rice, "Non-solvated aluminum hydride," Journal of the American Chemical Society, vol. 77, no. 11, pp. 3164-3165, 1955.
[57] F. M. Brower, N. E. Matzek, P. F. Reigler et al., "Preparation and properties of aluminum hydride," Journal of the American Chemical Society, vol. 98, no. 9, pp. 2450-2453, 1976.

[58] H. Nöth and E. Wiberg, Forschr Und Forsch, vol. 8, no. 3, p. 344, 1966.

[59] B. M. Bulychev, A. G. Burlakova, and P. A. Storozhenko, "Complex compounds of aluminum hydride ethoxide with mixed aluminum and boron hydrides with lithium and magnesium: compositions, physicochemical properties, and synthesis of unsolvated aluminum hydride," Zhurnal Neorganicheskoj Khimii, vol. 43, no. 5, pp. 829-836, 1998.

[60] H. C. Brown and N. M. Yoon, "Selective reductions. X. Reaction of aluminum hydride with selected organic compounds containing representative functional groups. Comparison of the reducing characteristics of lithium aluminum hydride and its derivatives," Journal of the American Chemical Society, vol. 88, no. 7, pp. 1464-1472, 1966.

[61] C. W. Heitsch, C. E. Nordman, and R. W. Parry, "The crystal structure and dipole moment in solution of the compound $\mathrm{AlH}_{3} \cdot 2 \mathrm{n}\left(\mathrm{CH}_{3}\right)_{3}$," Inorganic Chemistry, vol. 2, no. 3, pp. 508$512,1963$.

[62] F. Dallacker, K. W. Glombitza, and M. Lipp, "Derivate des methylendioxybenzols, III. Darstellung des 45-methylendioxy-phthalaldehyds," Justus Liebigs Annalen der Chemie, vol. 643, no. 1-3, pp. 67-82, 1961.

[63] L. W. Trevoy and W. G. Brown, "Mechanism of lithium aluminum hydride reactions," Journal of the American Chemical Society, vol. 71, no. 5, pp. 1675-1678, 1949.

[64] E. C. Ashby, J. R. Sanders, P. Claudy, and R. Schwartz, "Diethyl ether soluble aluminum hydride," Journal of the American Chemical Society, vol. 95, no. 19, pp. 6485-6486, 1973.

[65] A. E. Finholt, G. D. Barbaras, G. K. Barbaras, G. Urry, T. Wartik, and H. I. Schlesinger, "The preparation of sodium and calcium aluminium hydrides," Journal of Inorganic and Nuclear Chemistry, vol. 1, no. 4-5, pp. 317-325, 1955.

[66] W. Schwab and K. Wintersberger, "Uber darstellung und eigenschaften von calcium-aluminiumhydrid $\mathrm{Ca}\left(\mathrm{AlH}_{4}\right)_{4}$," Zeitschrift für Naturforschung, vol. 8, no. 11, pp. 690-691, 1953.

[67] B. M. Bulychev, A. V. Golubeva, P. A. Storozhenko, and K. N. Semenenko, "Synthesis of aluminum hydride compounds from sodium hydride and aluminum trichloride in diethyl ether," Zhurnal Neorganicheskoj Khimii, vol. 43, no. 8, pp. 1242-1245, 1998.

[68] E. C. Ashby, "A direct route to complex metal hydrides," Chemistry \& Industry, vol. 5, pp. 208-209, 1962.

[69] E. C. Ashby, G. J. Brendel, and H. E. Redman, "Direct synthesis of complex metal hydrides," Inorganic Chemistry, vol. 2, no. 3, pp. 499-504, 1963.

[70] B. Bogdanović, R. A. Brand, A. Marjanović, M. Schwickardi, and J. Tölle, "Metal-doped sodium aluminium hydrides as potential new hydrogen storage materials," Journal of Alloys and Compounds, vol. 302, no. 1-2, pp. 36-58, 2000.

[71] A. E. Finholt, A. C. Bond, and H. I. Schlesinger, "Lithium aluminum hydride, aluminum hydride and lithium gallium hydride, and some of their applications in organic and inorganic chemistry," Journal of the American Chemical Society, vol. 69, no. 5, pp. 1199-1203, 1947.

[72] M. Fichtner, C. Frommen, and O. Fuhr, "Synthesis and properties of calcium alanate and two solvent adducts," Inorganic Chemistry, vol. 44, no. 10, pp. 3479-3484, 2005. 
[73] E. Wiberg and R. Bauer, "Neues zur kenntnis des magnesium-aluminium-wasserstoffs $\mathrm{Mg}\left(\mathrm{AlH}_{4}\right)_{2}$," Zeitschrift für Naturforschung, vol. 7, no. 2, pp. 131-132, 1952.

[74] M. Fichtner, C. Frommen, and O. Fuhr, "Synthesis and properties of calcium alanate and two solvent adducts," Inorganic Chemistry, vol. 44, no. 10, pp. 3479-3484, 2005.

[75] T. N. Dymova, V. N. Konoplev, A. S. Sizareva, and D. P. Aleksandrov, "Magnesium tetrahydroaluminate: solid-phase formation with mechanochemical activation of a mixture of aluminum and magnesium hydrides," Koordinatsionnaya Khimiya, vol. 25, no. 5, pp. 312-315, 1999.

[76] H. Kabbour, C. C. Ahn, S. J. Hwang, R. C. Bowman Jr., and J. Graetz, "Direct synthesis and NMR characterization of calcium alanate," Journal of Alloys and Compounds, vol. 446, pp. 264-266, 2007.

[77] G. W. Schaeffer, J. S. Roscoe, and A. C. Stewart, "The reduction of iron (III) chloride with lithium aluminohydride and lithium borohydride: iron (II) borohydride," Journal of the American Chemical Society, vol. 78, no. 4, pp. 729-733, 1956.

[78] W. Grochala and P. P. Edwards, "Thermal decomposition of the non-interstitial hydrides for the storage and production of hydrogen," Chemical Reviews, vol. 104, no. 3, pp. 12831315, 2004.

[79] S. Orimo, Y. Nakamori, T. Kato, C. Brown, and C. M. Jensen, "Intrinsic and mechanically modified thermal stabilities of $\alpha$-, $\beta$ - and $\gamma$-aluminum trihydrides $\mathrm{AlH}_{3}$, , Applied Physics A, vol. 83, no. 1, pp. 5-8, 2006.

[80] S. Sartori, S. M. Opalka, O. M. Løvvik, M. N. Guzik, X. Tang, and B. C. Hauback, "Experimental studies of $\alpha$-AlD3 and $\alpha^{\prime}-\mathrm{AlD}_{3}$ versus first-principles modelling of the alane isomorphs," Journal of Materials Chemistry, vol. 18, no. 20, pp. 2361-2370, 2008.

[81] K. Tomiyasu, T. Sato, K. Horigane, S. Orimo, and K. Yamada, "Hydrogen release from $\mathrm{Li}$ alanates originates in molecular lattice instability emerging at $\sim 100 \mathrm{~K}, "$ Applied Physics Letters, vol. 100, Article ID 193901, 3 pages, 2012.

[82] P. Claudy, B. Bonnetot, and J. M. Letoffe, "Preparation and physicochemical properties of magnesium alanate," Journal of Thermal Analysis, vol. 15, no. 1, pp. 119-128, 1979.

[83] N. N. Mal'tseva, A. I. Golovanova, T. N. Dymova, and D. P. Aleksandrov, "Solid-phase formation of calcium hydridoaluminates $\mathrm{Ca}\left(\mathrm{AlH}_{4}\right)_{2}$ and $\mathrm{CaHAlH}_{4}$ upon mechanochemical activation or heating of mixtures of calcium hydride with aluminum chloride," Russian Journal of Inorganic Chemistry, vol. 46, no. 12, pp. 1793-1797, 2001.

[84] T. N. Dymova, D. P. Aleksandrov, V. N. Konoplev, T. A. Silina, and N. T. Kuznetsov, "Solid-phase reactions of aluminum $\left(\mathrm{AlH}_{3}\right)_{x}$ crystalline hydride-formation of alkali-metal tetrahydroaluminates and hexahydroaluminates," Koordinatsionnaya Khimiya, vol. 19, no. 7, pp. 529-534, 1993.

[85] B. Bogdanović, R. A. Brand, A. Marjanović, M. Schwickardi, and J. Tölle, "Metal-doped sodium aluminium hydrides as potential new hydrogen storage materials," Journal of Alloys and Compounds, vol. 302, no. 1-2, pp. 36-58, 2000.

[86] G. S. Sandrock, L. Suda, and L. Schlapbach, "Applications," in Hydrogen in Intermetallic Compounds II, L. Schlapbach, Ed., pp. 197-258, Springer, Berlin, Germany, 1992.

[87] W. de Graff, [Ph.D. thesis], University of Amsterdam, Amsterdam, The Netherlands, 1960.

[88] B. Baranowski, "Thermodynamics of metal-hydrogen systems at high-pressures," The Journal of Physical Chemistry, vol. 76, no. 8, pp. 714-724, 1972.
[89] J. Graetz, S. Chaudhuri, Y. Lee, T. Vogt, J. T. Muckerman, and J. J. Reilly, "Pressure-induced structural and electronic changes in $\alpha-\mathrm{AlH}_{3}$," Physical Review B, vol. 74, no. 21, Article ID 214114, 7 pages, 2006.

[90] M. Tkacz, S. Filipek, and B. Baranowski, "High-pressure synthesis of aluminum-hydride from the elements," Polish Journal of Chemistry, vol. 57, no. 4-6, pp. 651-653, 1983.

[91] B. Baranowski and M. Z. Tkacz, "The equilibrium between solid aluminum-hydride and gaseous-hydrogen," The Journal of Physical Chemistry, vol. 135, pp. 27-38, 1983.

[92] S. K. Konovalov and B. M. Bulychev, "The P,T-state diagram and solid phase synthesis of aluminium hydride," Inorganic Chemistry, vol. 34, no. 1, pp. 172-175, 1995.

[93] H. Saitoh, A. MacHida, Y. Katayama, and K. Aoki, "Formation and decomposition of $\mathrm{AlH}_{3}$ in the aluminum-hydrogen system," Applied Physics Letters, vol. 93, no. 15, Article ID 151918, 3 pages, 2008.

[94] J. Graetz, "New approaches to hydrogen storage," Chemical Society Reviews, vol. 38, no. 1, pp. 73-82, 2009.

[95] G. Sandrock, K. Gross, and G. Thomas, "Effect of Ti-catalyst content on the reversible hydrogen storage properties of the sodium alanates," Journal of Alloys and Compounds, vol. 339, no. 1-2, pp. 299-308, 2002.

[96] M. McCarty Jr., J. N. Maycock, and V. R. Pai Verneker, "Thermal decomposition of $\mathrm{LiAlH}_{4}$," Journal of Physical Chemistry, vol. 72, no. 12, pp. 4009-4014, 1968.

[97] G. Sandrock, K. Gross, G. Thomas, C. Jensen, D. Meeker, and S. Takara, "Engineering considerations in the use of catalyzed sodium alanates for hydrogen storage," Journal of Alloys and Compounds, vol. 330, pp. 696-701, 2002.

[98] S.-S. Liu, L.-X. Sun, Y. Zhang et al., "Effect of ball milling time on the hydrogen storage properties of $\mathrm{TiF}_{3}$-doped $\mathrm{LiAlH}_{4}$," International Journal of Hydrogen Energy, vol. 34, no. 19, pp. 8079-8085, 2009.

[99] Y. Kojima, Y. Kawai, M. Matsumoto, and T. Haga, "Hydrogen release of catalyzed lithium aluminum hydride by a mechanochemical reaction," Journal of Alloys and Compounds, vol. 462, no. 1-2, pp. 275-278, 2008.

[100] J. Chen, N. Kuriyama, Q. Xu, H. T. Takeshita, and T. Sakai, "Reversible hydrogen storage via titanium-catalyzed $\mathrm{LiAlH}_{4}$ and $\mathrm{Li}_{3} \mathrm{AlH}_{6}$," Journal of Physical Chemistry B, vol. 105, no. 45, pp. 11214-11220, 2001.

[101] D. Blanchard, H. W. Brinks, B. C. Hauback, P. Norby, and J. Muller, "Isothermal decomposition of $\mathrm{LiAlD}_{4}$ with and without additives," Journal of Alloys and Compounds, vol. 404-406, pp. 743-747, 2005.

[102] J. R. A. Fernandez, F. Aguey-Zinsou, M. Elsaesser et al., "Mechanical and thermal decomposition of $\mathrm{LiAlH}_{4}$ with metal halides," International Journal of Hydrogen Energy, vol. 32, no. 8, pp. 1033-1040, 2007.

[103] Z. Xueping and L. Shenglin, "Study on hydrogen storage properties of $\mathrm{LiAlH}_{4}$," Journal of Alloys and Compounds, vol. 481, no. 1-2, pp. 761-763, 2009.

[104] M. Ismail, Y. Zhao, X. B. Yu, and S. X. Dou, "Effects of NbF5 addition on the hydrogen storage properties of $\mathrm{LiAlH}_{4}$," International Journal of Hydrogen Energy, vol. 35, no. 6, pp. 2361-2367, 2010.

[105] T. Sun, C. K. Huang, H. Wang, L. X. Sun, and M. Zhu, "The effect of doping $\mathrm{NiCl}_{2}$ on the dehydrogenation properties of $\mathrm{LiAlH}_{4}$," International Journal of Hydrogen Energy, vol. 33, no. 21, pp. 6216-6221, 2008.

[106] R. A. Varin, L. Zbroniec, T. Czujko, and Z. S. Wronski, "The effects of nanonickel additive on the decomposition of complex metal hydride $\mathrm{LiAlH}_{4}$ (lithium alanate)," International 
Journal of Hydrogen Energy, vol. 36, no. 1, pp. 1167-1176, 2011.

[107] L. Hima Kumar, B. Viswanathan, and S. Srinivasa Murthy, "Dehydriding behaviour of $\mathrm{LiAlH}_{4}$ - the catalytic role of carbon nanofibres," International Journal of Hydrogen Energy, vol. 33, no. 1, pp. 366-373, 2008.

[108] P. J. Herley and O. Christofferson, "Decomposition of $\alpha$ aluminum hydride powder. 3. Simultaneous photolyticthermal decomposition," Journal of Physical Chemistry, vol. 85, no. 13, pp. 1887-1892, 1981.

[109] Rafi-Ud-Din, L. Zhang, L. Ping, and Q. Xuanhui, "Catalytic effects of nano-sized TiC additions on the hydrogen storage properties of $\mathrm{LiAlH}_{4}$," Journal of Alloys and Compounds, vol. 508, no. 1, pp. 119-128, 2010.

[110] H. Clasen, Germany Patent, 1141, 623, 1962.

[111] H. K. Birnbaum, C. Buckley, F. Zeides et al., "Hydrogen in aluminum," Journal of Alloys and Compounds, vol. 253-254, pp. 260-264, 1997.

[112] R. Zidan, B. L. Garcia-Diaz, C. S. Fewox, A. C. Stowe, J. R. Gray, and A. G. Harter, "Aluminium hydride: a reversible material for hydrogen storage," Chemical Communications, no. 25, pp. 3717-3719, 2009.

[113] M. J. Martinez-Rodriguez, B. L. Garcia-Diaz, J. A. Teprovich, D. A. Knight, and R. Zidan, "Advances in the electrochemical regeneration of aluminum hydride," Applied Physics A, vol. 106, no. 3, pp. 545-550, 2012.

[114] E. C. Ashby, "The direct synthesis of amine alanes," Journal of the American Chemical Society, vol. 86, no. 9, pp. 1882-1883, 1964.

[115] J. Graetz, S. Chaudhuri, J. Wegrzyn et al., "Direct and reversible synthesis of $\mathrm{AlH}_{3}$-triethylenediamine from $\mathrm{Al}$ and $\mathrm{H}_{2}$," Journal of Physical Chemistry C, vol. 111, no. 51, pp. 19148-19152, 2007.

[116] D. Lacina, J. Wegrzyn, J. Reilly, Y. Celebi, and J. Graetz, "Regeneration of aluminium hydride using dimethylethylamine," Energy and Environmental Science, vol. 3, no. 8, pp. 1099-1105, 2010.

[117] D. Lacina, J. Reilly, J. Johnson, J. Wegrzyn, and J. Graetz, "The reversible synthesis of bis(quinuclidine) alane," Journal of Alloys and Compounds, vol. 509, no. 2, pp. S654-S657, 2011.

[118] D. Lacina, J. Reilly, Y. Celebi, J. Wegrzyn, J. Johnson, and J. Graetz, "Regeneration of aluminum hydride using trimethylamine," Journal of Physical Chemistry C, vol. 115, no. 9, pp. 3789-3793, 2011.

[119] H. Clasen, "Alanat-synthese aus den elementen und ihre bedeutung," Angewandte Chemie, vol. 73, no. 10, pp. 322$331,1961$.

[120] J. Wang, A. D. Ebner, and J. A. Ritter, "Physiochemical pathway for cyclic dehydrogenation and rehydrogenation of $\mathrm{LiAlH}_{4}$, Journal of the American Chemical Society, vol. 128, no. 17, pp. 5949-5954, 2006.

[121] J. Graetz, J. Wegrzyn, and J. J. Reilly, "Regeneration of lithium aluminum hydride," Journal of the American Chemical Society, vol. 130, no. 52, pp. 17790-17794, 2008.

[122] X. Liu, G. S. McGrady, H. W. Langmi, and C. M. Jensen, "Facile cycling of Ti-doped $\mathrm{LiAlH}_{4}$ for high performance hydrogen storage," Journal of the American Chemical Society, vol. 131, no. 14, pp. 5032-5033, 2009.

[123] X. F. Liu, H. W. Langmi, S. D. Beattie, F. F. Azenwi, G. S. McGrady, and C. M. Jensen, "Ti-Doped $\mathrm{LiAlH}_{4}$ for hydrogen storage: synthesis, catalyst loading and cycling performance," Journal of the American Chemical Society, vol. 133, no. 39, pp. 15593-15597, 2011.
[124] T. Q. Hua and R. K. Ahluwalia, "Alane hydrogen storage for automotive fuel cells-off-board regeneration processes and efficiencies," International Journal of Hydrogen Energy, vol. 36, no. 23, pp. 15259-15265, 2011.

[125] R. K. Ahluwalia, T. Q. Hua, and J. K. Peng, "On-board and Off-board performance of hydrogen storage options for light-duty vehicles," International Journal of Hydrogen Energy, vol. 37, no. 3, pp. 2891-2910, 2012.

[126] L. Klebanoff, "5-year review of Metal Hydride Center of Excellence," Presentation at DOE $\mathrm{H}_{2}$ Program Annual Merritt Review, Washington, DC, USA, 2010. 

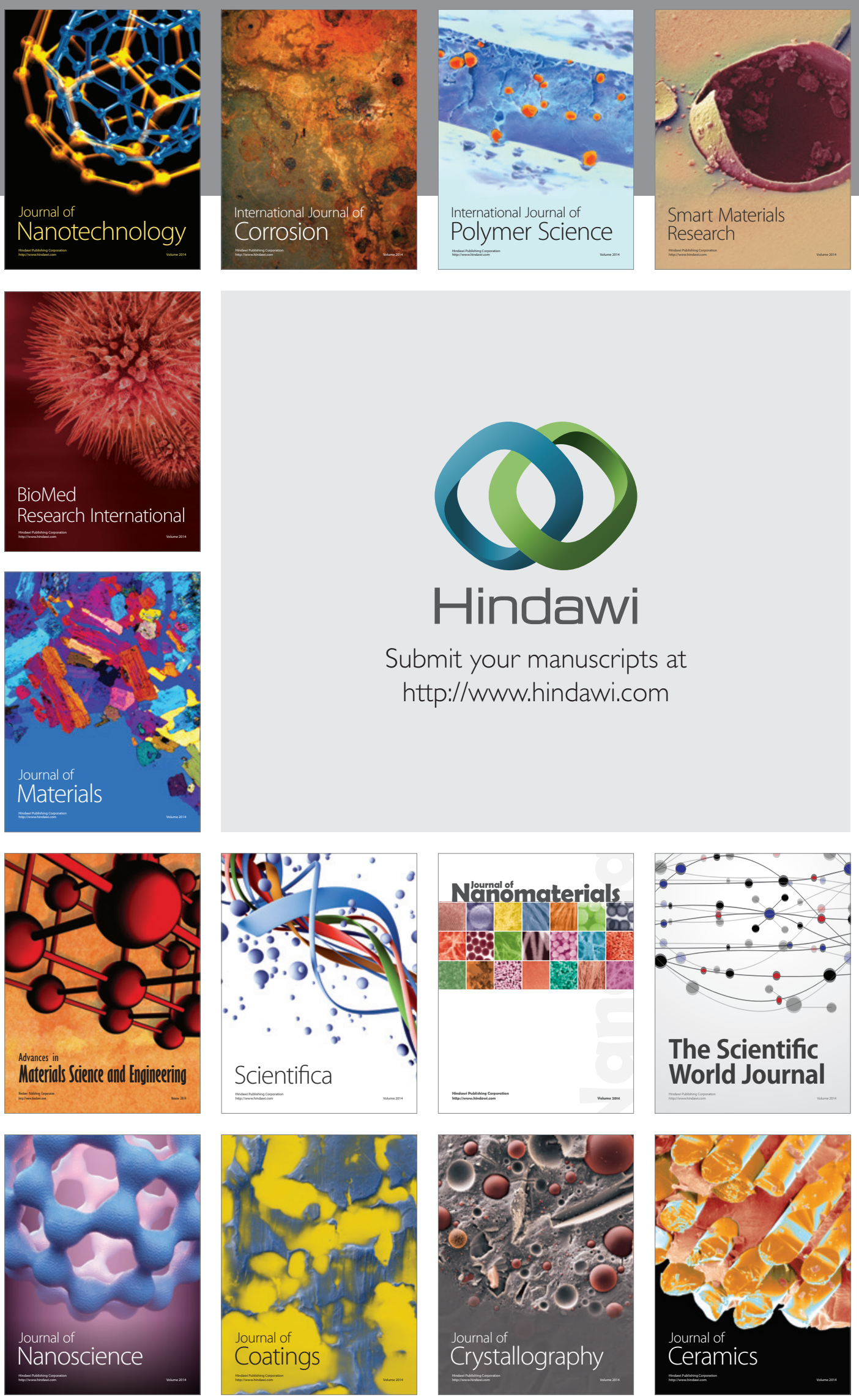

The Scientific World Journal

Submit your manuscripts at

http://www.hindawi.com

\section{World Journal}

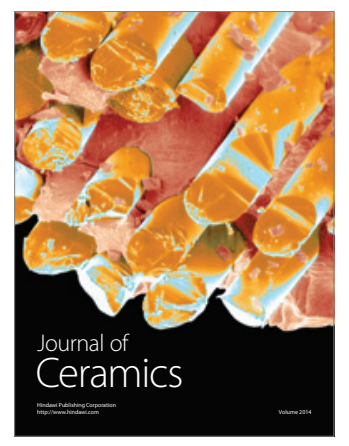

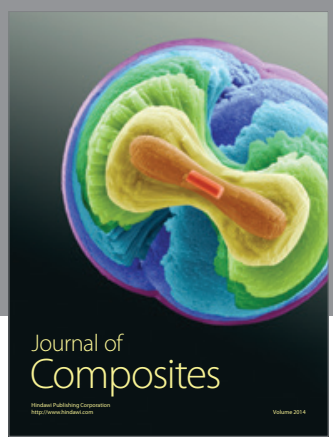
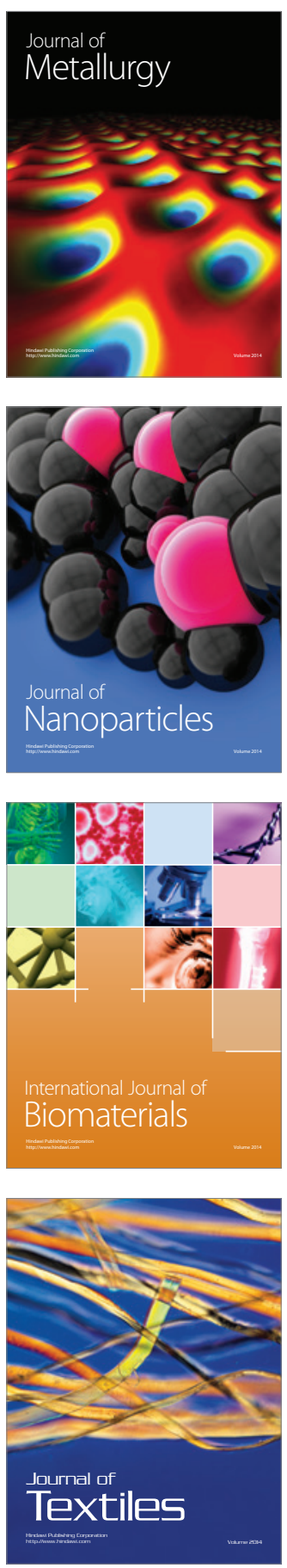